\title{
Recycling of Paleoplacer Gold through Mechanical and Postdepositional Mobilization in the Neoarchean Black Reef Formation, South Africa
}

\author{
G. T. Nwaila, ${ }^{1, \star}$ M. S. D. Manzi, ${ }^{1}$ J. Kirk, ${ }^{2} H$. K. Maselela, ${ }^{1}$ R. J. Durrheim, ${ }^{1}$ \\ D. H. Rose, ${ }^{3}$ P. C. Nwaila, ${ }^{4}$ L. C. Bam, ${ }^{5}$ and T. Khumalo ${ }^{1}$ \\ 1. School of Geosciences, University of the Witwatersrand, Private Bag 3, Wits, 2050, South Africa; 2. Geosciences \\ Department, University of Arizona, 1040 East Fourth Street, Tucson, Arizona 85721, USA; 3. Department of \\ Geology, University of Johannesburg, PO Box 524, Auckland Park 2006, South Africa; 4. PG Techno Wox, \\ 43 Patrys Avenue, Helikon Park, Randfontein, 1759, South Africa; 5. South African \\ Nuclear Energy Corporation (Necsa), PO Box 582, Pretoria, 0001, South Africa
}

\begin{abstract}
A B S T R A C T
The source of gold in the ca. $2.66 \mathrm{Ga}$ Black Reef Formation (BRF) has been investigated and constrained through petrographic, mineralogical, geochemical, and high-resolution three-dimensional reflection seismic data combined with drill core and underground geological mapping. The BRF is a strong seismic marker and consists of carbonaceous shale, quartz arenite, and conglomerate. Gold grade in the BRF is primarily controlled by the nature of the host conglomerates. Most of the gold in the BRF conglomerate occurs in native form, and its morphology is highly heterogeneous. Gold was initially introduced through mechanical recycling of underlying Witwatersrand reefs, followed by short-range (millimeter- to centimeter-scale) postdepositional alteration/remobilization associated with the Bushveld Complex and the Vredefort meteorite impact. Although the BRF was subjected to high postdepositional fluid circulation facilitated by high fracture density, the volume of dissolved gold was probably too small to form a large gold deposit, except in areas around the Black Reef/Witwatersrand reefs subcrop positions. Findings from this study demonstrate the importance of both sedimentological controls and impact-related structures in the formation of paleoplacer gold deposits during Neoarchean times.
\end{abstract}

Online enhancements: appendix, supplementary table and figure.

\section{Introduction}

Progressive depletion of minable gold reserves in the Witwatersrand Basin, South Africa, has triggered a significant amount of research on potential replacements. Several Witwatersrand-type gold occurrences exist elsewhere, such as the Huronian Basin in Canada, the Bababudan Basin in India, the Moeda Formation in Brazil, and the post-Witwatersrand Transvaal Basin in South Africa (Frimmel 2014). Witwatersrandtype gold deposits share certain similarities, such as the style of mineralization, granitoid-greenstone provenance, and the fact that they are almost ex-

Manuscript received July 18, 2018; accepted November 12, 2018; electronically published January 28, 2019.

* Author for correspondence; email: glen.nwaila@wits.ac.za. clusively hosted by conglomerate horizons commonly referred to as reefs. In the case of South Africa, the Neoarchean Black Reef Formation (BRF) gold deposit at the base of the Transvaal Supergroup is the youngest example of a Witwatersrand-type gold deposit (Henry and Master 2008). In most of the areas, the BRF is separated from the underlying auriferous strata of the Witwatersrand Supergroup by the Ventersdorp Supergroup, up to $8 \mathrm{~km}$ of basaltic and sedimentary rocks, including the gold-bearing Ventersdorp Contact Reef (VCR; Els et al. 1995). The BRF is of considerable economic interest because it contains economic concentrations of gold, especially in areas where it unconformably and directly overlies goldbearing conglomerates of the Witwatersrand and 
Ventersdorp Supergroups (e.g., the Driefontein gold mine in the Carletonville goldfield; fig. 1).

Proposed sources of the gold in the BRF are (1) reworked auriferous conglomerates of the Witwatersrand reefs (Frankel 1940; Germs 1982; Spellman 1986) and (2) postdepositional hydrothermal alteration (Graton 1930; Swiegers 1939; Barton and Hallbauer 1996; Gauert et al. 2010). Germs (1982) used sediment provenance, combined with high gold concentrations proximal to auriferous Witwatersrand conglomerates, to suggest that gold in theBRF was derived from erosion of the underlying Witwatersrand reefs and VCR. In support of the sedimentary-reworking hypothesis, Germs (1982) noted that gold occurs preferentially with minerals of detrital origin on sedimentary surfaces (e.g., bedding planes and cross beds). However, the evidence against the syngenetic placer model was provided by a study comparing the morphology and composition of detrital pyrite in the BRF to those of detrital and recrystallized (epigenetic) pyrite in the underlying Kimberley Reef of the Witwatersrand Supergroup (Barton and Hallbauer 1996). Those authors showed that detrital pyrite grains in the BRF are much larger than either the detrital or later recrystallized pyrite grains of the Kimberley Reef. A study by Frey et al. (1991) showed that the bulk of the gold in the BRF is texturally related to a complex $\mathrm{Zn}$ - $\mathrm{Pb}-\mathrm{Fe}-\mathrm{Co}-\mathrm{Ni}-\mathrm{Cu}$ sulfide/arsenosulfide mineral assemblage of epigenetic origin. Furthermore, Gauert et al. (2010) argued that abundant Ni-Co-Fesulfarsenides in the BRF, when compared to most of the Witwatersrand reefs, show that the BRF was affected by postdepositional hydrothermal fluids. More recently, Fuchs et al. (2016) argued that the BRF experienced intense postdepositional hydrothermal alteration by circulating hydrocarbon fluids (oils) that deposited native gold.

According to Sibson and Scott (1998) and Blenkinsop and Doyle (2014), structurally controlled stratabound gold mineralization has three main characteristics: (1) local shear zones control the orientation of the ore body; (2) gold mineralization is governed by fluid flow in a network of fractures and veins formed in response to a regional stress field; and (3) fault zones and their intersection points impart a directional permeability, so that the mineralizing fluids are channeled along dilatant zones. Almost all Precambrian basins have been affected by postdepositional alteration, affecting the chemical composition of the host rocks, and, in some places, the alteration can be linked to coeval gold mineralization and remobilization (Wallmach and Meyer 1990; Frimmel 1994; Phillips and Law 1994; Phillips and Powell 2015; Fuchs et al. 2016). In a hydrothermal system, the occurrence of gold mainly depends on tempera- ture, pressure, $\mathrm{pH}, \mathrm{Cl}^{-}$concentration, and fugacity of $\mathrm{H}_{2} \mathrm{~S}$ (Williams-Jones et al. 2009). In a system with $T>400^{\circ} \mathrm{C}$, gold mostly occurs as $\mathrm{AuCl}_{2}{ }^{-}$(Gammons and Williams-Jones 1997). Under such conditions, a decrease in temperature is the primary mechanism causing gold deposition. In contrast, $\mathrm{Au}(\mathrm{HS})_{2}{ }^{-}$is the dominant phase at $T<400^{\circ} \mathrm{C}$ (Cooke and Simmons 2000). Maximum solubility exists near the $\mathrm{H}_{2} \mathrm{~S}_{-} \mathrm{HS}^{-}$ $-\mathrm{SO}_{4}{ }^{2-}$ field, and with the decline of oxygen fugacity, the Au-S complex breaks down, leading to gold precipitation (Seward and Barnes 1997). Therefore, knowledge of the depositional environment and structural architecture, coupled with the postdepositional alteration history of a mineralized area, is key to understanding the formation, origin, and location of mineral deposits as well as to the exploration and finding of new targets.

This article is based on field and underground mapping and drill core sampling of the BRF. It proposes a model for the mechanical derivation of gold and regards the irregular shape of native gold as the culmination of postdepositional short-range remobilization. Exposures of the BRF have been examined in detail at the Carletonville goldfield (fig. 1). We present details of those features relevant to the genesis of gold, which were characterized with both mineralogicaland geochemical techniques. Furthermore, this study utilizes high-resolution three-dimensional (3D) reflection seismic data, acquired for gold exploration in the Carletonville goldfield (Manzi et al. 2013), to assist in delineating faults and fractures that form the likely conduits for postdepositional gold-bearing fluid flow.

\section{Geological Setting}

The 2.67-2.10 Ga Transvaal Supergroup is a sedimentary succession that is preserved in three structural basins on the Kaapvaal Craton, namely, the Transvaal and Griqualand West basins in South Africa and the Kanye Basin in Botswana (Altermann and Nelson 1998; Knoll and Beukes 2009). The BRF is a widespread sedimentary unit located at its base (Els et al. 1995). It lies unconformably on rocks of the Witwatersrand and Ventersdorp Supergroups and an older granitoid-greenstone basement (Master 1984). The BRF has never been dated directly. Detrital zircon age constraints from felsic rocks of the underlying Ventersdorp Supergroup (Armstrong et al. 1991) and tuffs from the upper Oaktree Formation in the basal Chuniespoort Group above the BRF (Martin et al. 1998) provide lower (ca. 2.71 Ga) and upper (ca. $2.59 \mathrm{Ga}$ ) age limits for the BRF. By stratigraphic equivalence, using the Wolkberg Group units elsewhere, the best available age constraint for the BRF is 2.66 Ga (Sumner and Beukes 2006). 

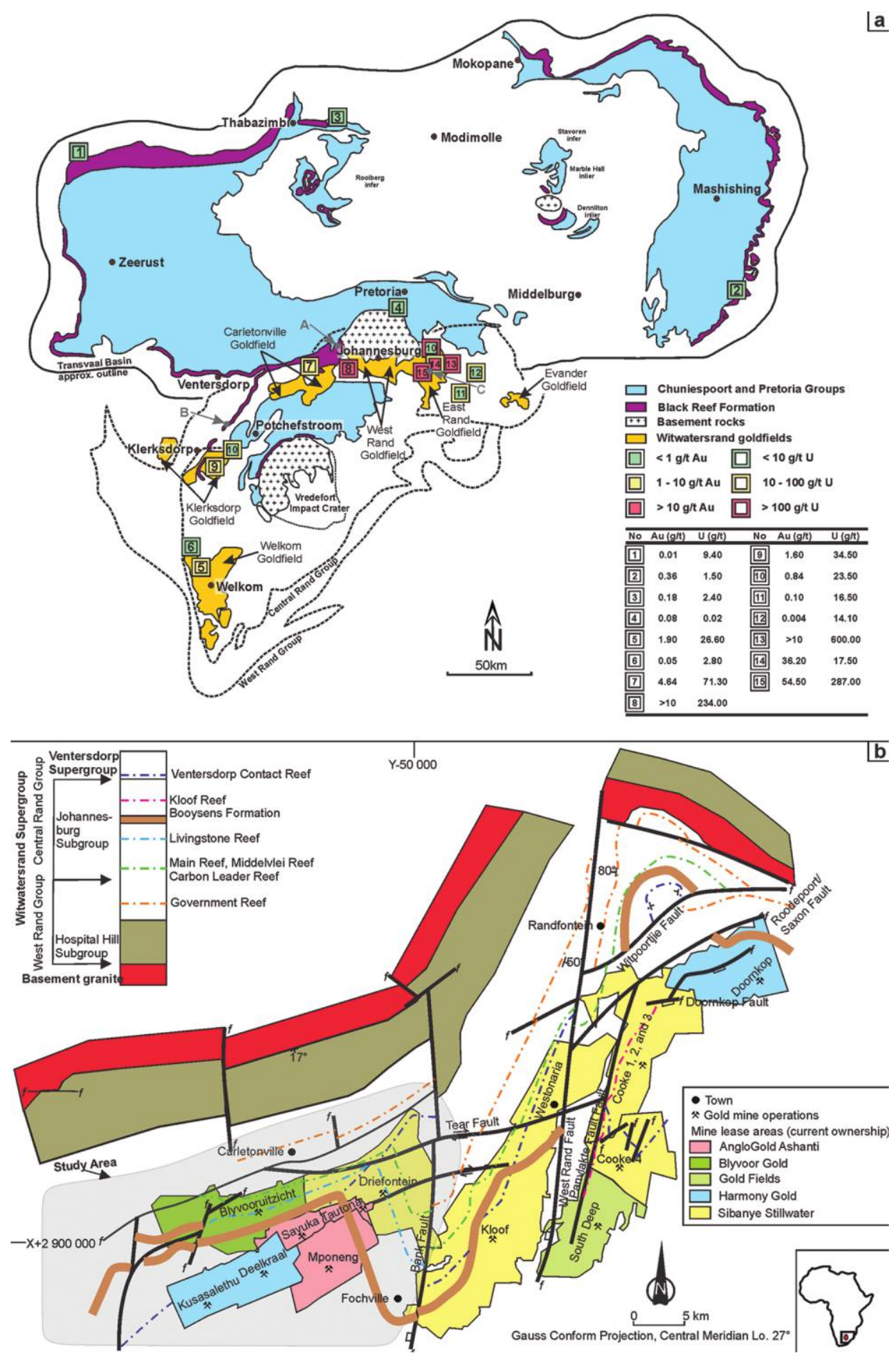

Figure 1. a, Simplified geological map of the Transvaal Supergroup, including the Witwatersrand goldfields, showing gold and uranium concentrations of the Black Reef Formation (modified after Eriksson et al. 2006; Fuchs et al. 2016). The numbered boxes are color coded to reflect metal grade. $b$, Location map of the West Rand and West Wits Line (Carletonville) goldfields of the Witwatersrand Basin in South Africa, showing mine boundaries and the location of the study area. 
In areas where the BRF contains economic gold, the paleotopographic surface is characterized by deep erosional features, with paleochannels incising the underlying gold-rich strata of the Witwatersrand and Ventersdorp Supergroups (Barton and Hallbauer 1996). Paleocurrent directions indicate that the sediment was provided from the north, northeast, and west of the basin (Barton and Hallbauer 1996), similar to the inferred source regions for the Witwatersrand Supergroup. The BRF comprises a lower quartz arenite unit (ca. $14 \mathrm{~m}$ in thickness), with a sporadically developed conglomerate $10 \mathrm{~cm}-11 \mathrm{~m}$ in thickness) at the base overlain by black carbonaceous shale and siltstone intercalations and interbedded shale and dolomite beds in the upper portion. In some areas, especially closer to the base of the formation, the conglomerate forms an upward-fining sequence with a quartz arenite that locally contains scattered pebbles grading upward into a commonly black, carbonaceous, shale unit (Frey et al. 1991). In the Carletonville goldfield, the BRF conglomerate thickness increases from west to east and attains maximum thickness proximal to the Witwatersrand reefs and the VCR. Above the BRF, the Transvaal Supergroup is divided into the ca. 2.55-2.43 Ga Chuniespoort Group and the ca. 2.35-2.10 Ga Pretoria Group. Geophysically, the BRF forms a strong seismic reflector as a result of a significant impedance contrast between the overlying dolomitic rocks of the Chuniespoort Group and underlying rocks of the Ventersdorp Supergroup (Manzi et al. 2013). The Chuniespoort Group comprises dolomite, banded iron formations, and shale (Eriksson et al. 2006). The Chuniespoort Group dolomite locally contains base metal ore occurrences and deposits such as $\mathrm{Cu}, \mathrm{Pb}$, Cr, Ni, Sn, and Zn (Clay 1986; Meyer and Robb 1996). The rocks of the Transvaal basin were intruded by the Bushveld Igneous Complex at $2.06 \mathrm{Ga}$ (Zeh et al. 2015).

\section{Samples and Analytical Methods}

Samples. A total of 39 representative BRF samples taken from underground mines in the Carletonville goldfield, $70 \mathrm{~km}$ west of Johannesburg at latitude $26^{\circ} 24^{\prime} \mathrm{S}$ and longitude $27^{\circ} 30^{\prime} \mathrm{E}$ (fig. 1), were selected for mineralogical and geochemical characterization: 21 samples are from the basal quartz pebble conglomerates, 12 samples are from the lower quartz arenite unit (above the basalquartz pebble conglomerates), and six are from the carbonaceous shale intercalated with siltstone. The sampling strategy involved the collection of specimens that showed well-preserved primary sedimentary structures and textures with no visible oxidation features.
Mineralogical Analyses. The first aliquot was pulverized in an agate mill and analyzed by X-ray diffraction (XRD) with a Panalytical X'pert Pro diffractometer employing Co-K $\alpha$ radiation at the University of Johannesburg. The XRD analyses were used to identify the crystalline phases present in the sample. The limitation of XRD is that it is only semiquantitative and can detect only crystalline mineral phases with abundances of $>3 \mathrm{vol} \%$. The second aliquot was used to make polished thin sections. The Olympus BX63 transmitted-/reflected-light microscope was applied for petrography and microstructural observations, to study mineralogical assemblages, textures, and paragenesis. Images from the optical microscope were captured by a normal light-sensitive camera in order to generate photomicrographs. The third aliquot was mounted onto a resin block, polished, and carbon coated before it was placed into an FEI 600F field emission mineral liberation analyzer (MLA) at the University of Johannesburg. The MLA was used to identify the presence of Au and U minerals and carbonaceous minerals through image analysis. The fourth aliquot was scanned with a Nikon XTH 225L microfocus X-ray computed tomography (microXCT) unit (Nikon Metrology, Leuven, Belgium) located at the MIXRAD (Micro-focus X-ray Radiography and Tomography) laboratory at the South African Nuclear Energy Corporation, Pelindaba. Scanning parameters were set to $87 \mathrm{keV}$ and $192 \mu \mathrm{A}$ to optimize sample contrast for better mineral discrimination. The use of micro-XCT enables a detection size of $11 \mu \mathrm{m}$ and permits visualization of the smallest particles and fractures in rocks and minerals. A 0.1-mm-thick aluminium filter was used to approximate a homogeneous X-ray beam spectrum by removing the lower-energy photons. The samples were securely mounted in a polystyrene mold to avoid any movement during each scan. The mounted specimens were then placed onto a rotating sample manipulator that facilitated scanning at $360^{\circ}$. Two thousand projection images were obtained in the $360^{\circ}$ scan at 0.5-s exposure time for each projection. An average of two projections was applied to minimize noise within the images, which resulted in a good-quality scan. The scans were then reconstructed with Nikon CTPro software and further analyzed with VGStudio Max V2.2 (Volume Graphics, Heidelberg, Germany).

Geochemical Analyses. Major- and trace-element concentrations were determined at Intertek Genalysis Laboratory (Perth, Australia) with a combination of analytical methods (i.e., X-ray fluorescence $[\mathrm{XRF}]$ for major elements, inductively coupled plasma mass spectrometry [ICP-MS] for trace elements, fire assays for Au determination, and LECO induction furnace instruments for carbon and sulfur 
determination). The mean and standard deviation of the geochemical data are presented in the following manner: if the mean of a specific element (e.g., $\mathrm{Ni}$ ) is 300 and the sample standard deviation is 29 , the values are reported as $\bar{x}=300 \pm 29$.

Major- and Trace-Element Analyses. Major- and trace-element concentrations (table S1; tables S1 and $\mathrm{S} 2$ and fig. $\mathrm{S} 1$ are available online) were obtained by XRF spectrometry and ICP-MS on fusion glass disks. Procedural blanks and several standard reference materials (AMIS0283, AMIS0192, and OREAS series [25a, 45d, 45e] standards) were used to monitor data quality. Loss on ignition was determined after previously dried powders were heated to a temperature of $950^{\circ} \mathrm{C}$. A PANalytical MINPAL4 XRF spectrometer was used to determine the majorelement concentrations. The instrument is equipped with a side-window $\mathrm{Rh}$ tube with maximum $30 \mathrm{kV}$, maximum $1 \mathrm{~mA}$, maximum $9 \mathrm{~W}$, and an energydispersive Si drift detector. The sample chamber was flushed with He to lower the detection limits and reduce analytical errors. The analytical error for most of the elements are $<0.10 \%$ (relative), except for $\mathrm{MgO}$ $(0.50 \%)$ and $\mathrm{Na}_{2} \mathrm{O}(3.40 \%)$.

An Agilent 7700x quadrupole ICP-MS equipped with a Photon-Machines Analyte 193 excimer laser ablation system and a Helex two-volume ablation cell was used to determine the trace-element concentrations in lithium borate flux-fused beads. Helium was used as the carrier gas. The analyses were performed at a laser repetition rate of $10 \mathrm{~Hz}$ and a laser pulse energy of $4 \mathrm{~J} \mathrm{~cm}^{-2}$ and on the largest spot possible $(63 \mu \mathrm{m})$. Continuous line-scan analyses were conducted with a preablation step and a $5-\mu \mathrm{m} \mathrm{s}^{-1}$ scanning speed. Samples were assessed in cycles of approximately 15 analyses, and these were bracketed by analyses of each standard (AMIS0283, AMIS0192, and OREAS 25a, 45d, and 45e). The GLITTER software package (van Achterbergh et al. 2001) was used for the offline selective integration of time-resolved signal intensities and the calculation of the element concentrations, detection limits, and $1 \sigma$ uncertainties. The detection limits were $0.001 \mathrm{wt} \%$ for major elements, $0.50 \mathrm{ppm}$ for trace elements (except $\mathrm{Cr}$ [20 ppm]; Sr [0.20 ppm]; Sc and V [10 ppm]; and Sn, W, $\mathrm{Zn}$, and $\mathrm{Zr}[1 \mathrm{ppm}])$, and $0.10 \mathrm{ppm}$ for rare earth elements (REEs). Replicate analyses of the samples indicated that absolute precision for the major elements was better than $1 \%$, whereas the precision for trace elements in relative percentage standard deviation was $5 \%$. The reported $\mathrm{Fe}_{2} \mathrm{O}_{3}$ content represents the total Fe content. All major- and trace-element data were normalized against the post-Archean Australian shale (PAAS) composite values of Taylor and McLennan (1985) because of the absence of reliable
Archean reference data. Most of the recent literature also utilizes the PAAS reference for comparative reasons, rather than an Archean shale composite, because of the consistency of the former standard (Smith et al. 2013; Nwaila et al. 2017).

Lead Collection Fire Assay, New Pot with an ICP-MS Finish (Method FA25N/MS). The Au content was determined by fire assay following a dry procedure by furnace methods. $\mathrm{PbO}$ fire assay is a more effective collection method for $\mathrm{Au}$ than the nickel sulfide (NS25) method (Intertek Genalysis Laboratory). Twenty-five grams of pulped sample was mixed with a PbO-based flux and ignited in a furnace. New pots were used to preclude the possibility of a minute amount of cross contamination of the precious metals. The $\mathrm{PbO}$ was reduced to $\mathrm{Pb}$ by the presence of an organic reducing agent. The molten $\mathrm{Pb}$ was miscible with the precious metals but immiscible with the slag. The $\mathrm{Pb}$ thus collects the precious metals and sinks to the bottom of the melt, where it coalesces to form a button. The melt was poured into a conical mold, where it was allowed to cool. The $\mathrm{Pb}$ button was separated from the slag and hammered into a cube to facilitate handling. The cupellation stage involves oxidation of the $\mathrm{Pb}$ button. $\mathrm{Pb}$ buttons were placed in magnesia cupels in a furnace, where they melted and oxidized. The $\mathrm{PbO}$ was absorbed by the cupel, leaving the precious metals behind, which coalesced into a prill as a result of surface tension. The presence of a small amount of silver in the flux allows for a prill of manageable size. This was transferred into a polypropylene test tube, digested in aqua regia, measured for volume, and diluted for analysis by ICP-MS. The use of sensitive instrumentation such as ICP-MS enables lower detection limits (e.g., Abou-Shakra 2003), such as $1.00 \mathrm{ppb}$ for $\mathrm{Au}$. Internal standards were used to correct for instrument drift and plasma fluctuations. The results were corrected for the catch weight by the laboratory information management system. Based on duplicate measurements of the samples (table S2; quality control certified reference materials, blank samples and detection limits), the relative standard deviation is $\leq 10 \%$ for all analyses. To test the accuracy and precision of the analyses, replicate analyses of each of the certified reference materials (AMIS0283, AMIS0192, and OREAS 25a, 45d, and 45e) were performed (table S2).

Total Organic Carbon-Total Sulfur Analysis. Total organic carbon (TOC) and total sulfur (TS) were analyzed in an Eltra Infrared CS-2000 LECO analyzer with a detection limit of $0.01 \%$ at Intertek Laboratory in Perth. The pulped sample was weighed out and placed in a ceramic crucible. A fluxing agent was added to improve fluidity and oxidation of the car- 
bon and sulfur. Heating was accomplished in a highfrequency induction furnace, as this provides both speed and accuracy. Any sulfur or carbon was converted to $\mathrm{SO}_{2}$ or $\mathrm{CO}_{2}$, respectively. These gases absorb infrared radiation at specific wavelengths that are proportional to the concentration of the $\mathrm{C}$ or $\mathrm{S}$ in the sample. Any water in the sample was removed by passing the gases produced through magnesium perchlorate, as water interferes with the analysis. Calibration was conducted with a standard (OREAS 45d) of known $\mathrm{C}$ and $\mathrm{S}$ concentration and a control blank.

Detection of Faults and Fractures Using 3D Seismic Attributes. In this article, we used ant-tracking technique (volumetric attribute) to detect fractures in the seismic volume and an edge-detection attribute (horizon attribute) to enhance detection of subseismic faults that crosscut the BRF. Ant-tracking and edgedetection attributes are available in the Petrel software of Schlumberger. Ant tracking emulates the behavior of ant colonies in nature and how they use pheromones to mark their paths to optimize the search for food (Pedersen et al. 2002; Nkosi et al. 2018). Similarly, virtual ants are put as seeds on a seismic volume to search for fault and fracture zones. Virtual pheromones deployed by the ants capture information related to the fault/fracture zones in the volume. The result is a seismic attribute volume that exhibits very sharp and detailed fault/fracture networks, since it better enhances horizon discontinuities when compared to other traditional edgeenhancing attributes (e.g., chaos and variance attributes). In this study, ant-tracking attribute was applied to the seismic cube, to automatically extract faults and compare the results. The workflow for the ant-tracking algorithm had the following main steps:

1. The edge-enhancing attribute was computed to reduce noise in the data (data preconditioning) and was used as input for the ant-tracking computation. The goal was to enhance major $(\geq 25-\mathrm{m}$ throw) and subtle (e.g., faults with $<25-\mathrm{m}$ throw) geological structures that fall below the vertical seismic resolution limit (a quarter of a dominant seismic wavelength, i.e., $25 \mathrm{~m}$ for these data).

2 . The variance and chaos attributes (volumetric attributes) were computed to enhance major faults (Nkosi et al. 2018). Variance and chaos attributes measure the "lack of organization" in the dip-andazimuth estimation method. These algorithms were generated on the fly (virtual seismic volumes) in a small area of the cube to find the best parameters for better detection of faults. As the variance cube better enhanced the faults and fractures, it was used as input for the computation of the ant-tracking attribute.
Edge-detection attribute is a horizon attribute developed by Rock Deformation Research (2004) and implemented in the Petrel software. The edge-detection algorithm combines dip and azimuth variations, normalized to the local noise of the surface, and is designed to detect subtle geological features that cannot be detected by the dip and dip-azimuth attributes (Rijks and Jauffred 1991). This technique was computed to the manually picked and gridded BRF seismic horizon to provide high-resolution imaging of structures such as faults, dikes, and fractures and to increase the number of structures imaged. The parameters (e.g., grid cell, dip, and azimuth) were chosen to improve the lateral resolution of the fault traces, which aids in characterizing fault/fracture continuity and connectivity.

\section{Results}

Geological Mapping and 3D Reflection Seismic Imaging. Geological mapping of the BRF in the Carletonville goldfield was mainly limited to underground exposures and drill cores. The key aspects identified during geological mapping were (1) sedimentological characteristics, (2) Au grade distribution, (3) the nature of lithological/structural contacts, (4) alteration types and patterns, and (5) fault and vein orientations. Underground exposures of the Black Reef were visited at all Carletonville goldfield mines between 2010 and 2017, as shown in figure $1 b$. This was supplemented by data from additional borehole core material. Extensive underground mining excavations (e.g., crosscuts, raise lines, and stopes), which dip perpendicular to the BRF strike direction, expose the Black Reef conglomerate and its footwall quartz arenite and hanging-wall shale over distances of up to $4 \mathrm{~km}$. Quite often, the restricted height of the underground excavations (e.g., $2.5 \mathrm{~m}$ ) results in either the top or the bottom of the Black Reef conglomerates being exposed.

The results indicate that $\mathrm{Au}$ concentrations in the range of $5-11 \mathrm{~g} \mathrm{t}^{-1}$ are associated with conglomerates that are well packed with quartz pebbles that range in size from 23 to $45 \mathrm{~mm}$. The conglomerates are matrix supported and are embedded in a black matrix that has abundant pyrobitumen (fig. $2 a-2 c$ ). A variety of dispersed, nodular, and fracture-controlled modes of pyrobitumen occurrence are evident. Quartz pebbles are locally associated with chert pebbles and are rounded to subrounded. The quartz pebbles commonly have microfractures in them that contain pyrobitumen. Except for pyrobitumen, the composition of the BRF conglomerates is similar to those of the VCR and the upper Witwatersrand reefs in hand- 


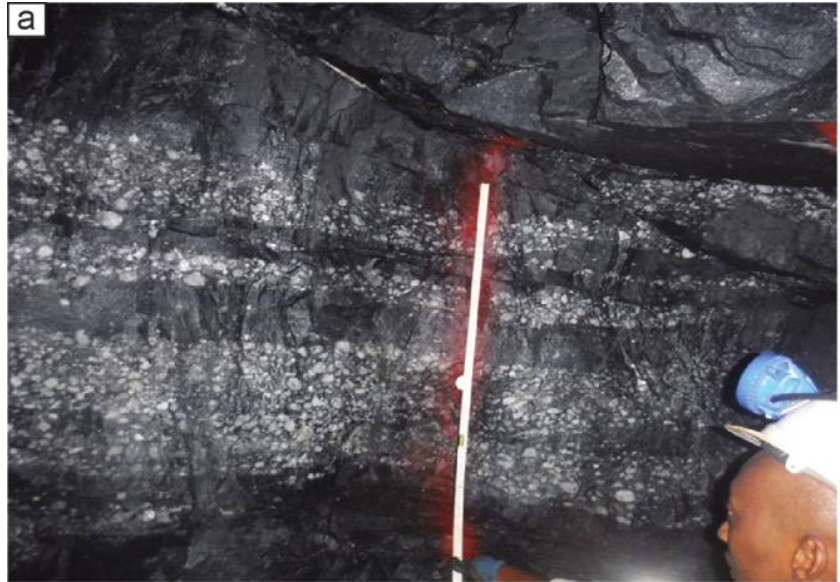

C

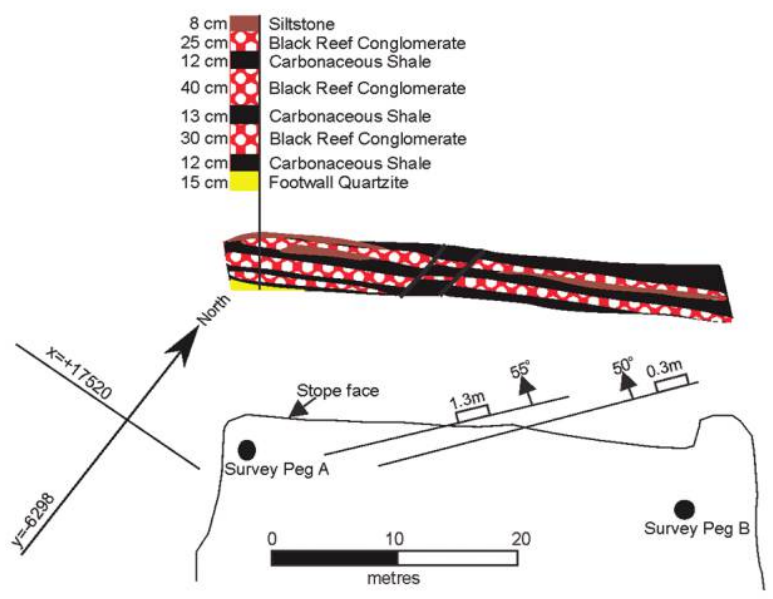

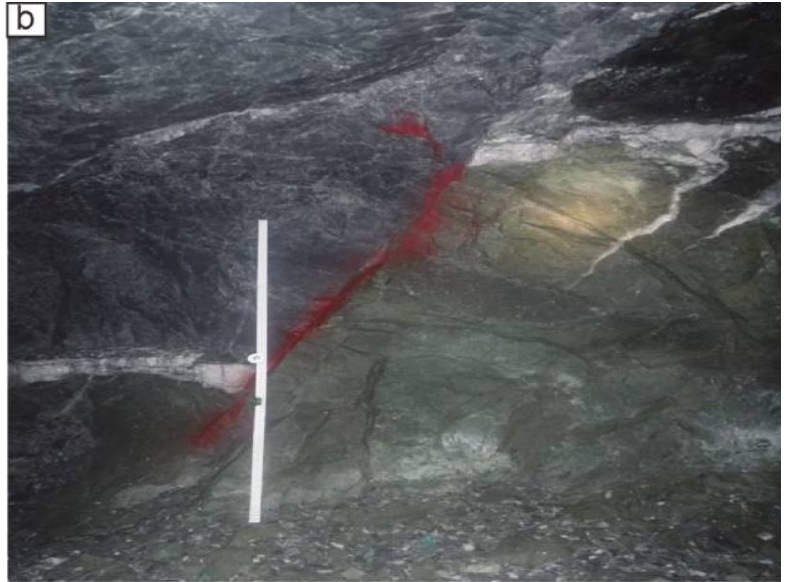

d
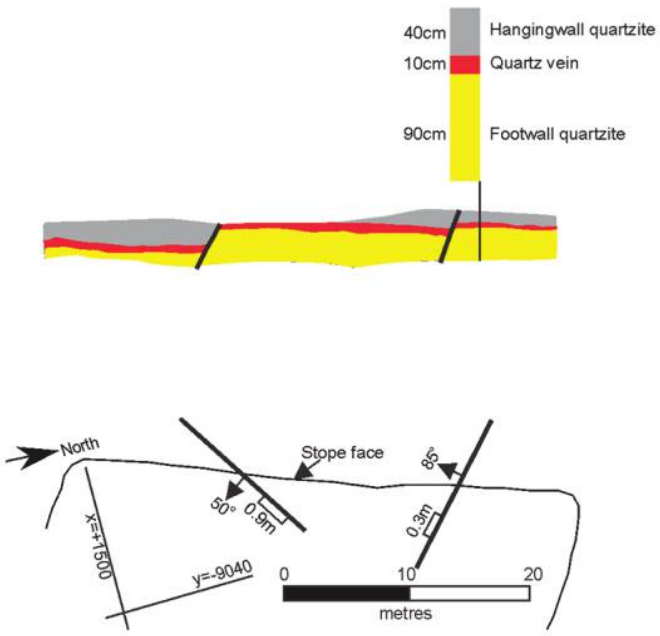

e

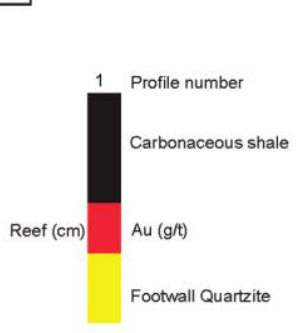

NNW

SSE

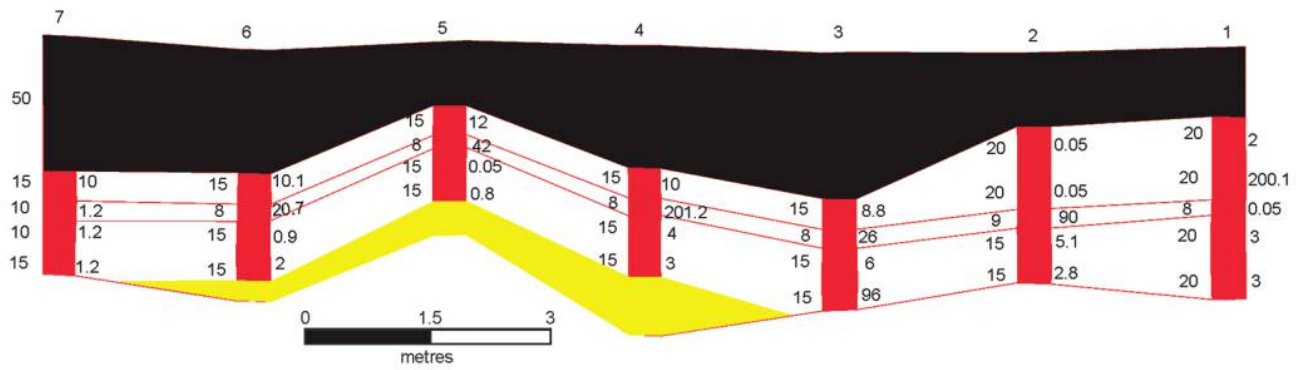

Figure 2. Underground geological data. $a$, Multicyclic auriferous conglomerate of the Black Reef Formation. $b$, Quartz vein lode cut by normal fault. $c$, Sidewall profile of multicycling auriferous conglomerate, showing minor faulting. $d$, Sidewall profile of quartz vein lode, showing tectonic contact and minor faults. $e$, Sampling profile of the reef zone.

specimen samples. Subrounded pyrite particles up to $1.8 \mathrm{~mm}$ in diameter were observed. Moderately mineralized reefs of the BRF have Au concentrations of ca. $2 \mathrm{~g} \mathrm{t}^{-1}$, and they are associated with a pebbly medium- to coarse-grained quartz arenite that has scattered quartz pebbles with a particle size ranging from 13 to $27 \mathrm{~mm}$, hosted in a black carbonaceous matrix. Where Au grades are $<2 \mathrm{~g} \mathrm{t}^{-1}$, the rock type is mainly a dark gray, coarse- to medium-grained quartz arenite that grades to a fine-grained quartz arenite 
with pyrite particles that are $\sim 0.6 \mathrm{~mm}$. Carbonaceous shale intercalated with siltstone overlies the reef zone and is rich in pyrite nodules that are $0.01 \mathrm{~mm}$ in diameter. The pyrite nodules are found in both the siltstone and the shales of the BRF. In some places, carbonaceous shales are intercalated with Au-rich conglomerates. The gradual decrease in pebble size, increase in quartz arenite proportion, and narrowing of the lowermost conglomerate band in the reef zone are consistent with the proximity to the underlying auriferous conglomerates of the Witwatersrand and Ventersdorp Supergroups. Detailed underground mapping and sampling confirmed that gold grades of 5-7 $\mathrm{g} \mathrm{t}^{-1}$ are locally enhanced (up to $200 \mathrm{~g} \mathrm{t}^{-1}$ ) along essentially strata-bound quartz-pyrite-gold veins (fig. $2 b$, $2 d, 2 e)$. The localized Au enrichment is common along tectonic contacts filled by quartz veins. Visible gold is rare, except in crosscutting quartz-sulfide veins.

The highest gold grades in the BRF are proximal to the reefs of the Witwatersrand and Ventersdorp
Supergroups (see fig. 3). In the Carletonville goldfield, the Driefontein operation (D7 and D8 in fig. 3a) is the only active mining operation where the Black Reef crops against more than two underlying reefs (fig. $3 b$, $3 c)$. Below the well-mineralized reef zone is a dark gray, chloritized, coarse-grained quartz arenite. The quartz arenite becomes lighter gray away from the mineralized reef zone. Potassic alteration is common throughout the BRF. At a local scale, the BRF exhibits variable strike and dip across the study area, which is a result of complex folding, warping, and faulting. Underground mapping shows that the BRF strikes in a northeasterly direction at an average dip of $5^{\circ}-15^{\circ}$ to the southeast. A series of fractures accompanying both normal and reverse faults of $<2$-m throw are common in the reef zone and the country rocks (fig. $2 c$, 2d). Dolerite and nepheline syenite dikes crosscut the BRF and are often associated with highly jointed, dark gray, recrystallized quartz arenite. Reviews by Hanson et al. (2006) and Cawthorn (2015) confirmed
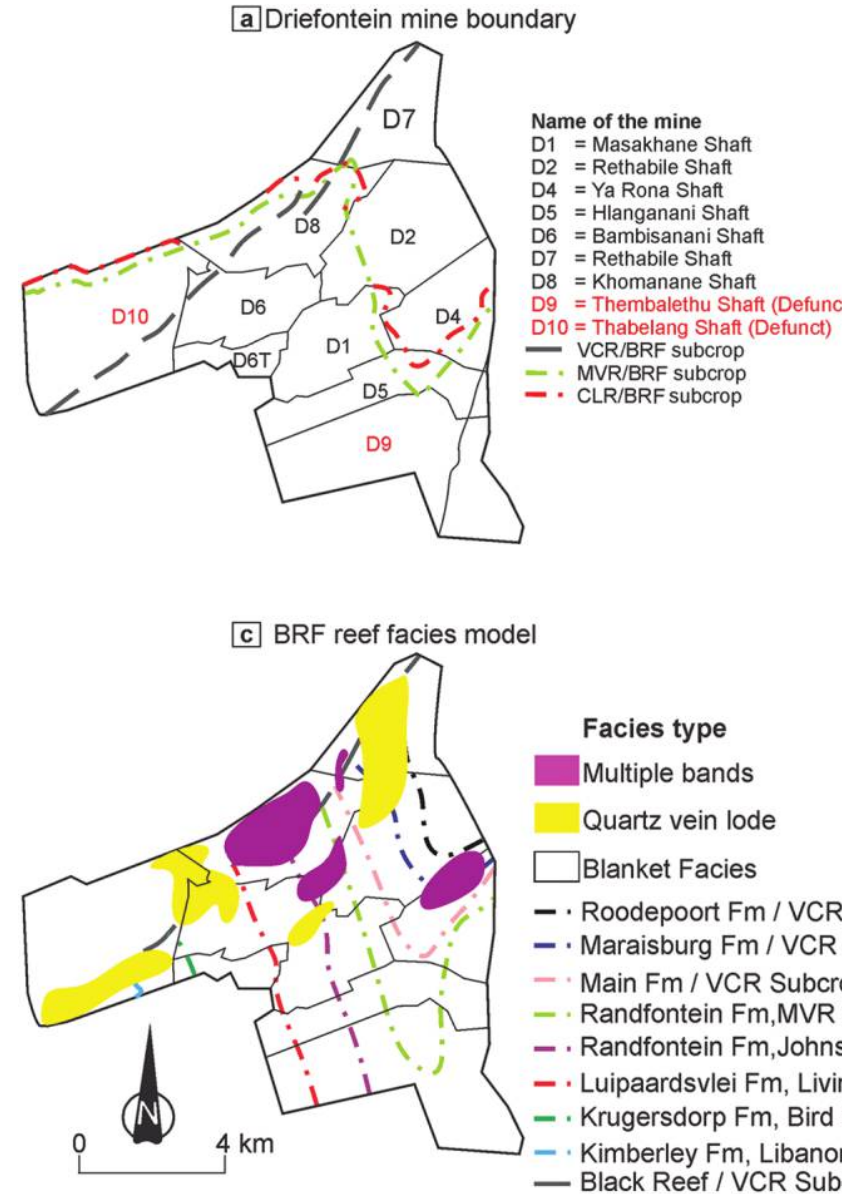

b Simplified geological cross-section of Driefontein operations

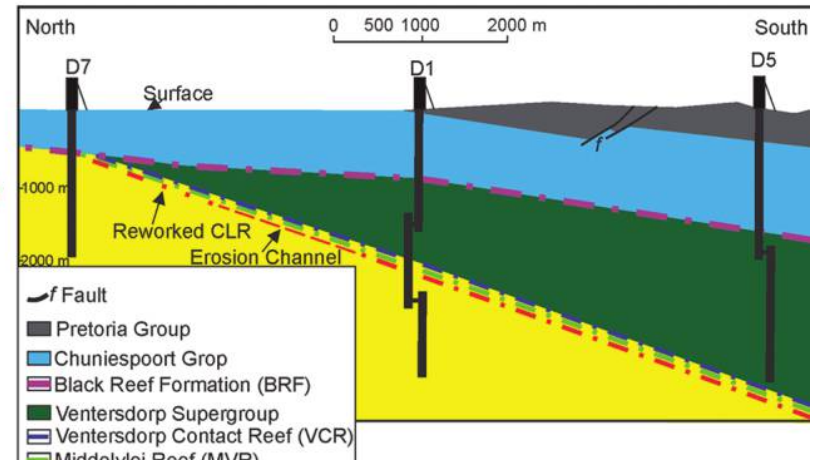

d BRF grade distribution model
Facies type

Multiple bands

Quartz vein lode

Blanket Facies

- - Roodepoort Fm / VCR Subcrop

- Maraisburg Fm / VCR Subcrop

- Main Fm / VCR Subcrop

- Randfontein Fm,MVR / VCR Subcrop

- Randfontein Fm,Johnstone Reef / VCR Subcrop

- · Luipaardsvlei Fm, Livingstone Reef / VCR Subcrop

- . Krugersdorp Fm, Bird Reef / VCR Subcrop

- . Kimberley Fm, Libanon Reef / VCR Subcrop — Black Reef / VCR Subcrop

Figure 3. $a$, Overview of the Driefontein operation. $b$, Simplified geological cross section of the Driefontein operations. $c$, Facies model of the Black Reef Formation. $d$, Gold distribution in the Black Reef Formation in the Driefontein operations. 
the nature of the dikes and their crosscutting relationship with older sequences, including the BRF.

In addition to the underground mapping, we carefully applied a series of 3D seismic attributes (Manzi et al. 2013, 2015) to the 3D reflection seismic data to enhance detection of faults (or fractures) and dikes affecting the BRF, with vertical displacements below the traditional resolution criteria (fig. 4a). The edgedetection attribute computed for the BRF horizon is helpful in enhancing the definition of major and subtle (as indicated by white and black arrows, respectively, in fig. 4a) but pervasive faults and fractures with displacements as small as $1-2 \mathrm{~m}$ that cannot be easily seen using conventional interpretation methods (e.g., depth structure maps and seismic sections). Most major faulting occurs in the southeastern region of the BRF horizon, and these faults are mainly north-northeast trending (highlighted by a black boundary in fig. 4a). Generally, the edgedetection map shows that minor faults ( $<2$-m throw) in the BRF are heterogeneously distributed and locally form fracture networks (fig. 4a). In seismic sections (fig. $4 b, 4 c$ ), the seismic data show that the BRF is highly deformed; for example, the sections exhibit a north-trending, upright, open anticline, with a crest that is cut by a series of west-dipping reverse faults and normal faults that define horsts and grabens.

To further enhance the structural resolution, we applied the ant-tracking technique to the seismic volume to particularly optimize the imaging of fracture networks (fig. 5a). While fractures with little to no vertical offset are difficult to map on vertical seismic sections, they cause changes in seismic-wave propagation that may cause scattering of the incident seismic energy, thereby attenuating the amplitude of higher frequencies. As observed in figure 5, the ant-tracking technique reveals further evidence of faulting and fracturing that is not resolvable on conventional seismic sections. For example, the data show that Transvaal Supergroup strata are severely compartmentalized by complex geological structures (e.g., fractures indicated by red arrows in fig. $5 a, 5 b)$ such as multifault segments, multiple bifurcations from a single plane to form a branched fault array, and fractures and dikes that crosscut fault systems (fig. $5 a, 5 b)$. Further inspection of the data along the depth slice $(\sim 2 \mathrm{~km}$; fig. $5 c$ ) suggests that the volume is characterized by a subtle, complex architectural character such as heterogeneous fracture density, clustering of fractures around the fault zones, crosscutting fault/fracture relationships, and connectivity and continuity of fractures (as shown by yellow and blue arrows, respectively). We also note that most of the fractures that crosscut the BRF can be tracked from the overlying strata (at ca. $500 \mathrm{~m}$ depth) down to the underlying
Witwatersrand strata (at ca. $4 \mathrm{~km}$ depth), thereby providing evidence for structural linkage between the Transvaal and Witwatersrand strata (fig. 5).

Mineralogy. Whole-rock mineralogical analyses (XRD) of the BRF lithology are listed in table A1; tables A1-A4 are available online. The major and minor minerals present in the conglomerate samples are quartz, muscovite, chlorite, monazite, pyrite, chromite, galena, sphalerite, gold, uraninite, brannerite, zircon, and pyrobitumen. This mineralogical assemblage is similar to that of the Witwatersrand and Ventersdorp Supergroup rocks (Ramdohr 1958; Minter 1976; Phillips and Powell 2015; Frimmel 2018). Pyrobitumen, which is dispersed through the rock, fills microfractures in quartz pebbles, and occurs disseminated in quartz cement, is a specific feature of the BRF. Pyrite is common in the BRF conglomerate samples (fig. 6). Pyrite types were distinguished on the basis of their morphology and include detrital pyrite (i.e., massive, rounded, and inclusion-bearing pyrite) and diagenetic and/or epigenetic pyrite types (fig. 6). Detrital pyrite and epigenetic pyrite types were distinguished on the basis of evidence of abrasion, as described by da Costa et al. (2017). Barton and Hallbauer (1996), McLoughlin (2014), and Fuchs et al. (2016) also observed a similar range of pyrite types in the BRF in the East Rand goldfield, distinguishing them on morphological, chemical, and isotopic grounds. In some places, detrital pyrite occurs in stringers parallel to bedding planes. Most pyrite grains have undergone subsequent fracturing (fig. 6). Trace amounts of detrital (i.e., uraninite and zircon) and epigenetic (i.e., chalcopyrite, galena, sphalerite, chromite, brannerite, and monazite) phases also occur in the conglomerate samples. In the conglomerate samples, clasts reach $45 \mathrm{~mm}$ in size and consist mainly of polycrystalline quartz. Very coarse, mainly monocrystalline quartz sand dominates the matrix. Gold occurs as coarse, randomly distributed, irregular grains within fractured quartz clasts (fig. $6 a$ ) and rounded blebs (fig $6 b$ ). Fine sericite, chlorite, and pyrobitumen are also present. The matrix assemblage varies only slightly throughout the sample set. Pyrobitumen with various textures and forms is widespread, particularly in the shales and matrix of the conglomerates (fig. $6 b$ ). The fracture-filling form of pyrobitumen is of particular interest, as it indicates mobility of hydrocarbons. Gold occurs both along bedding planes associated with pyrite and within various forms of pyrobitumen (fig. 6). Irregularly shaped and jagged-edge gold particles occur between various pyrite particles (fig. 6b). Sericitization was observed in the conglomerate matrix (fig. $6 d$ ). Native gold associated with pyrite and healed fractures were also observed (fig. $6 e, 6 f$ ). 


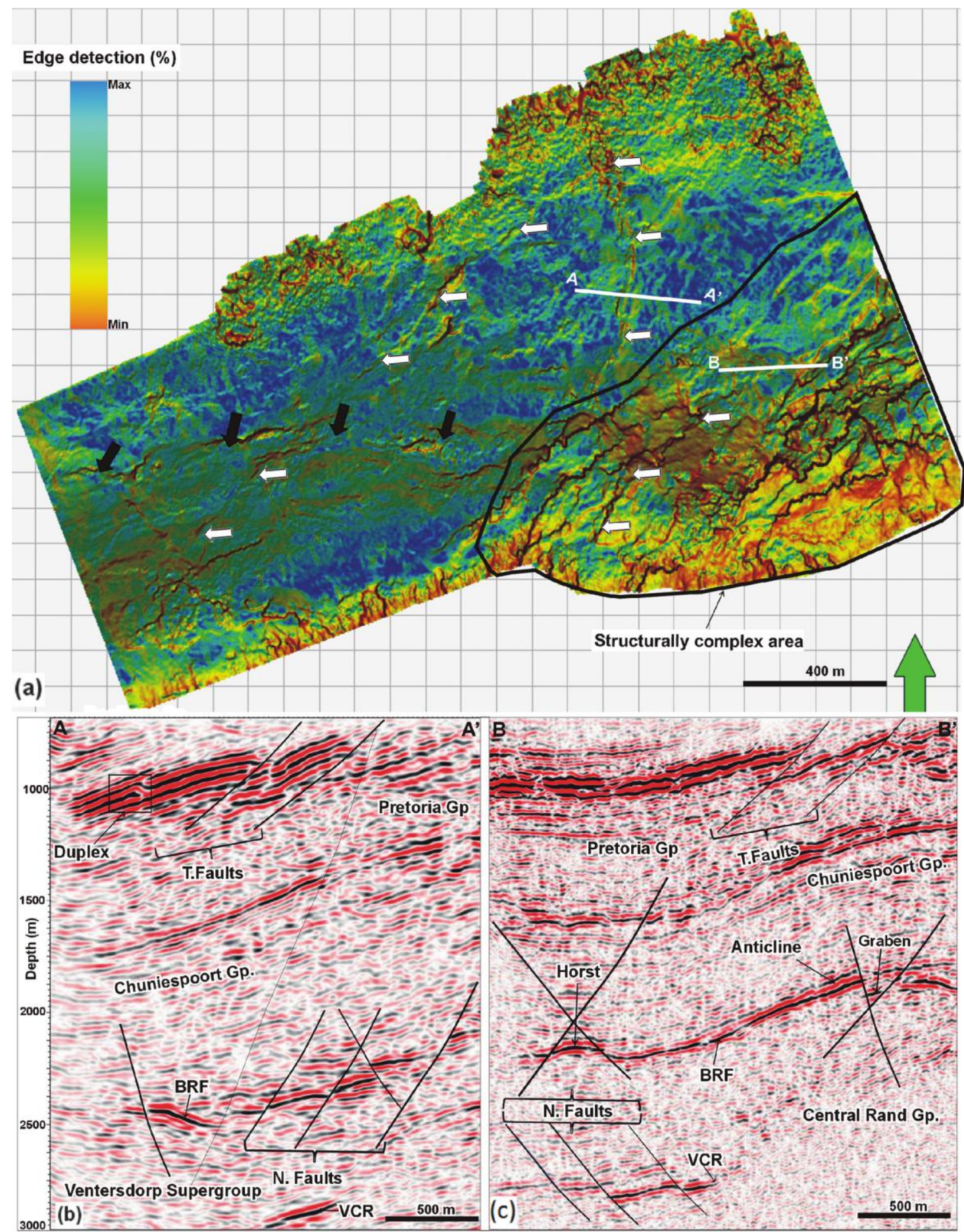

Figure 4. a, Edge-detection attribute computed for the Black Reef Formation (BRF), showing a highly structurally complex BRF (arrows show trends of major and minor structures that crosscut the BRF). The edge-detection algorithm combines dip and azimuth variations, normalized to the local noise surface, which overcomes the difference in detectability between the dip and dip-azimuth attributes. Multicolored strips represent the subtle discrete or sharp edges on the horizon, which can be associated with low-throw faults. The minimum on the scale represents fractures and minor faults $(<25-\mathrm{m}$ throw). The map covers the Kusasalethu, Savuka, and Mponeng gold mines and the western part of the Driefontein mine (see fig. $1 b$ for locations). $b$, Seismic section extracted from the seismic volume, showing the seismic imaging of duplexes, thrust (T. Faults) and normal faults (N. Faults). $c$, Seismic section extracted from the seismic cube, showing an interpreted anticline and faults bounding grabens and horsts. Note that the Transvaal Supergroup is deformed by the anticline and that the Ventersdorp Supergroup is partially eroded, thus bringing the underlying strata of the Central Rand Group closer to the BRF. Gp = Group; VCR = Ventersdorp Contact Reef. 

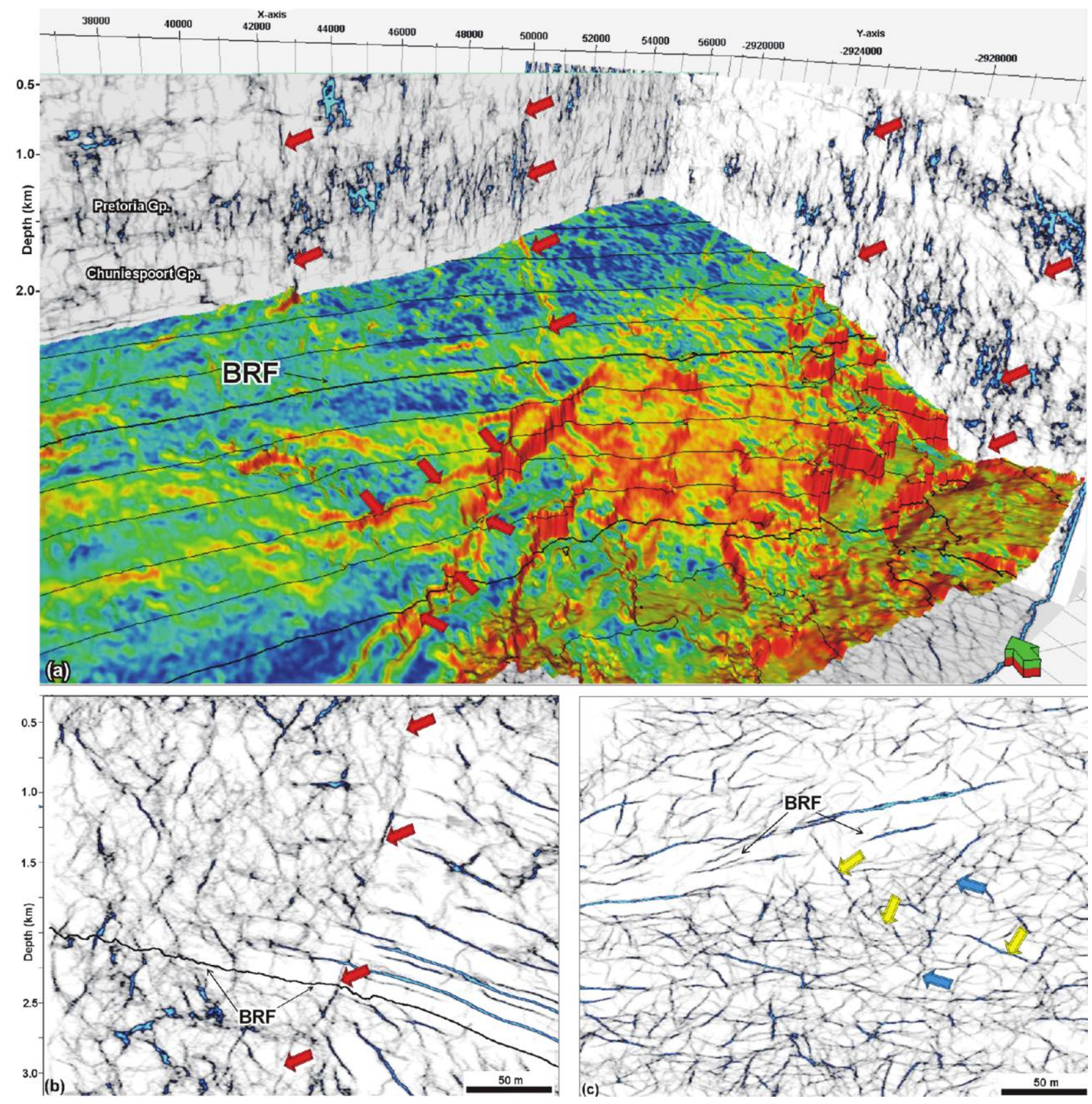

Figure 5. a, Three-dimensional visualization of combined Black Reef edge-detection surface and enhanced threedimensional fracture density delineation using the ant-tracking technique (color bar for edge-detection attribute is given in percent; see fig. 4a). The ant-tracking volume shows the vertical and lateral continuity of fractures (red arrows). $b$, Seismic section extracted from the ant-tracked seismic volume, showing the high-resolution imaging of the continuity (red arrows) of fractures that crosscut the Black Reef Formation (BRF) and overlying and underlying strata, aiding in characterizing bifurcations and crosscutting relationships. c, Seismic depth slice extracted from $2 \mathrm{~km}$ of the seismic volume, showing complex heterogeneous architectures of the fractures and the high interconnectivity and crosscutting relationship between fractures (blue and yellow arrows, respectively) that offset the BRF, underlying and overlying strata.

Within the pyrobitumen nodules, uraninite and brannerite were observed (fig. 7). With MLA data, it can be calculated from the modal mineralogy of the bulk samples that the uraninite makes up the majority of the uranium-bearing phases $(88 \%-90 \%)$, while the brannerite makes up the remaining $10 \%-$ $12 \%$. The uraninite in the reef samples occurs in two forms. In the first and most common instance, the 

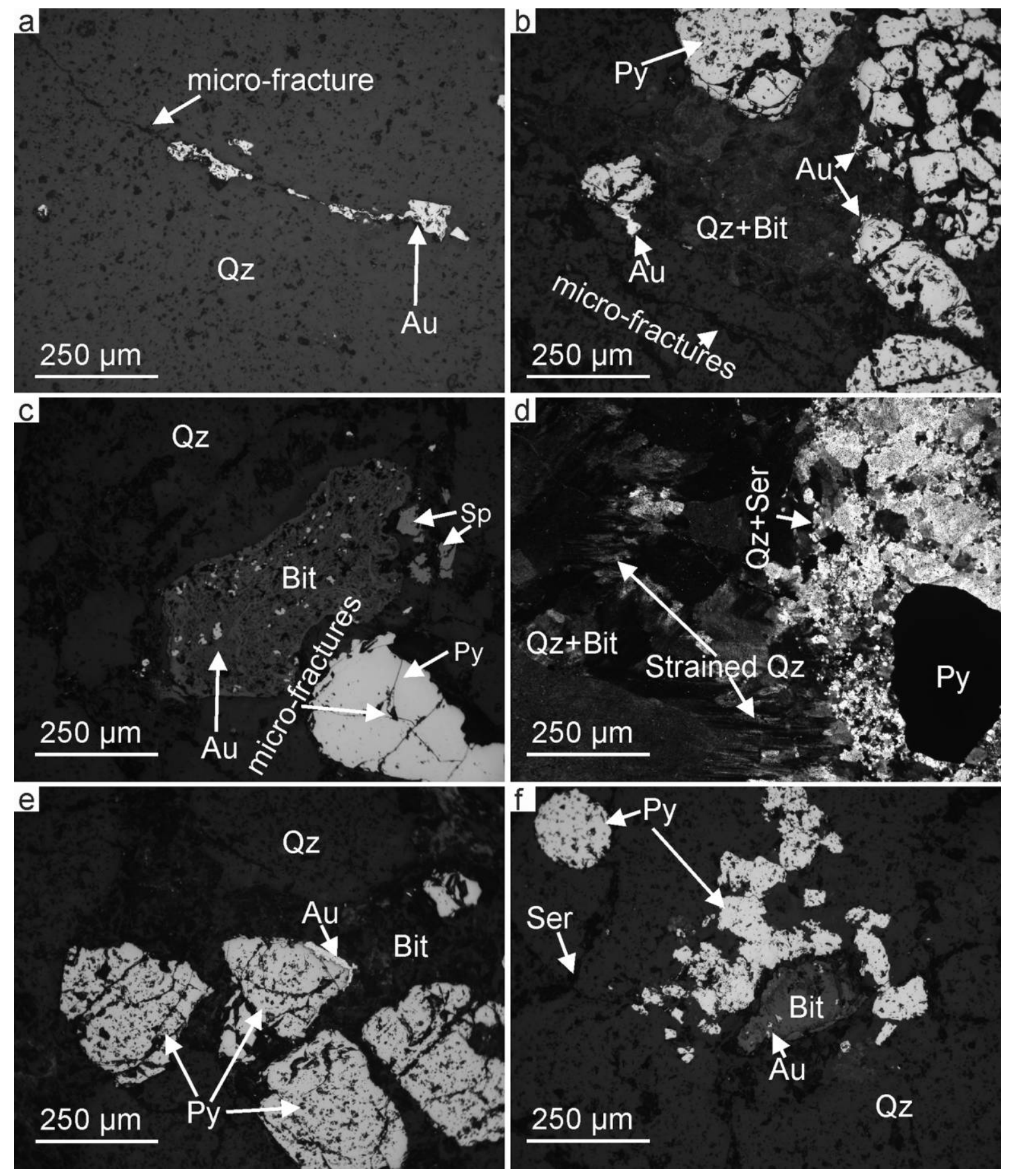

Figure 6. Reflected-light microscopy $(a-c, e, f)$ and transmitted-light microscopy $(d)$ images of samples of the Black Reef conglomerates in the Carletonville goldfield. $a$, Fractured quartz pebble filled with native gold. $b$, Irregular native gold at the edges of pyrite. $c$, Pyrobitumen nodule filled with gold. $d$, Strained quartz and sericitization around quartz pebbles. $e$, Pyrite with carbon inclusions and elongated native gold. $f$, Various forms of pyrite and pyrobitumen nodule. Au = native gold; Bit $=$ pyrobitumen; $\mathrm{Qz}=$ quartz; $\mathrm{Py}=$ pyrite; Ser $=$ sericite; $\mathrm{Sp}=$ sphalerite. A color version of this figure is available online.

uraninite occurs enclosed within carbon nodules (fig. $7 a$ ). In the second instance, the uraninite occurs with brannerite along the grain boundaries of the pyrite grains and polymerized in carbon (fig. $7 b$ ).
The major uranium mineral in the BRF is irregularly shaped uraninite that, in many cases, is indistinguishable from its finely dispersed and intergrown alteration minerals, such as brannerite, coffinite, and 

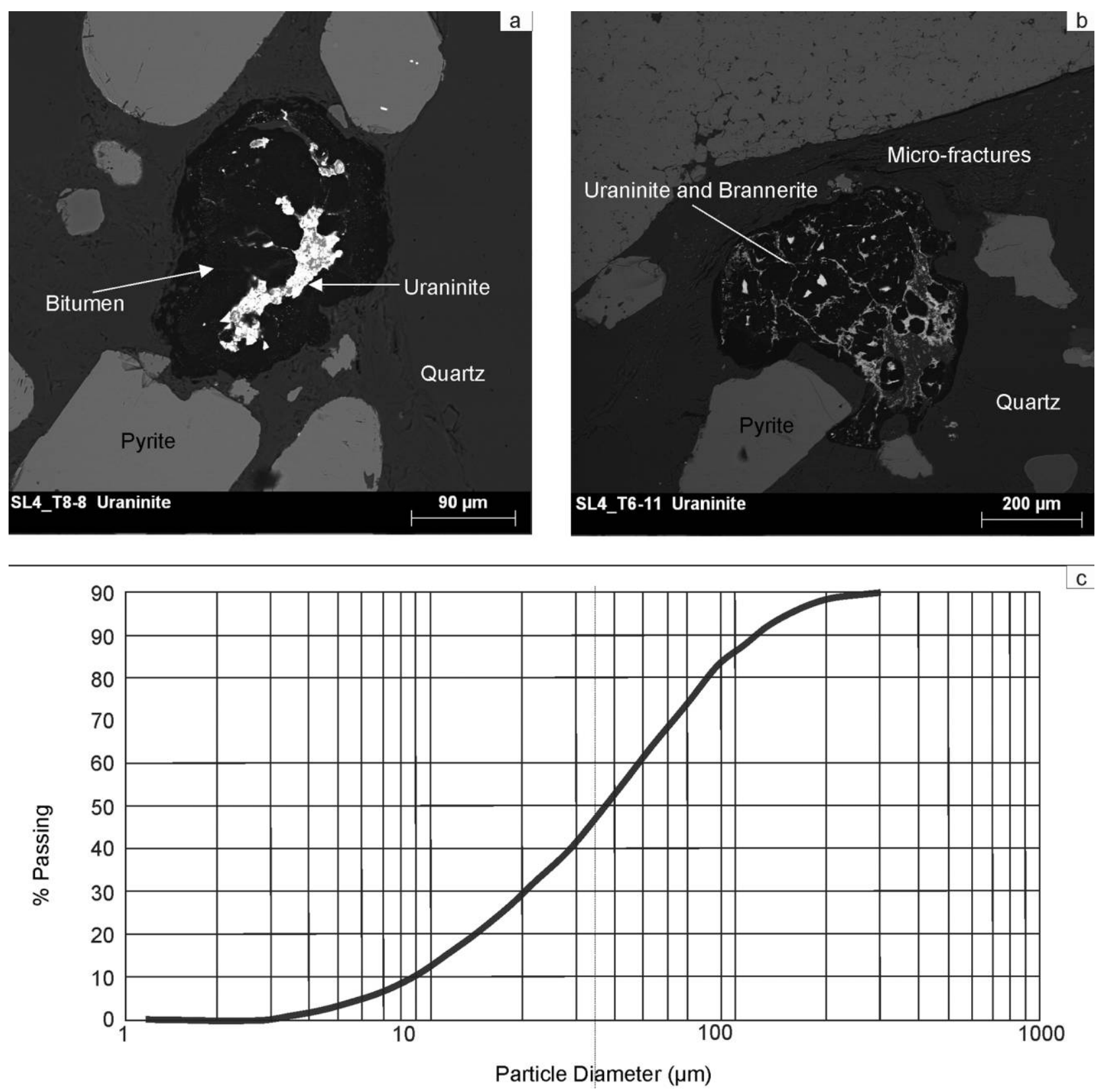

Figure 7. Back-scattered electron images of uraniferous phases acquired from the mineral liberation analyzer. $a$, Uraninite in pyrobitumen nodules surrounded by pyrite. $b$, Fractured carbon nodule. $c$, Uraninite particle size distribution curve. A color version of this figure is available online.

xenotime (fig. $7 b$ ). This occurrence of $U$ mineral phases has also been observed in the BRF in the East Rand goldfield (Fuchs et al. 2016). The majority of the uraninite inclusions are between 2 and $90 \mu \mathrm{m}$ in equivalent circular diameter (ECD; fig. $7 c$ ). Despite the fact that brannerite is often found within the same carbon nodules as uraninite, there are fewer particles of brannerite than particles of uraninite. The brannerite particles are also usually smaller than the uraninite particles.
Gold also varies significantly in shape and size, with most of the gold particles having an irregular shape. This is in contrast with some of the Witwatersrand reefs (e.g., the Basal Reef in the Welkom goldfield), which comprise toroidal gold particles (Minter 1999). There is a strong association of gold with quartz, pyrite, and pyrobitumen (fig. 8a). It should be noted that not all the carbon nodules contain gold. Most of the detrital pyrite occurs along bedding planes (fig. 8b). Gold is fairly coarse grained 

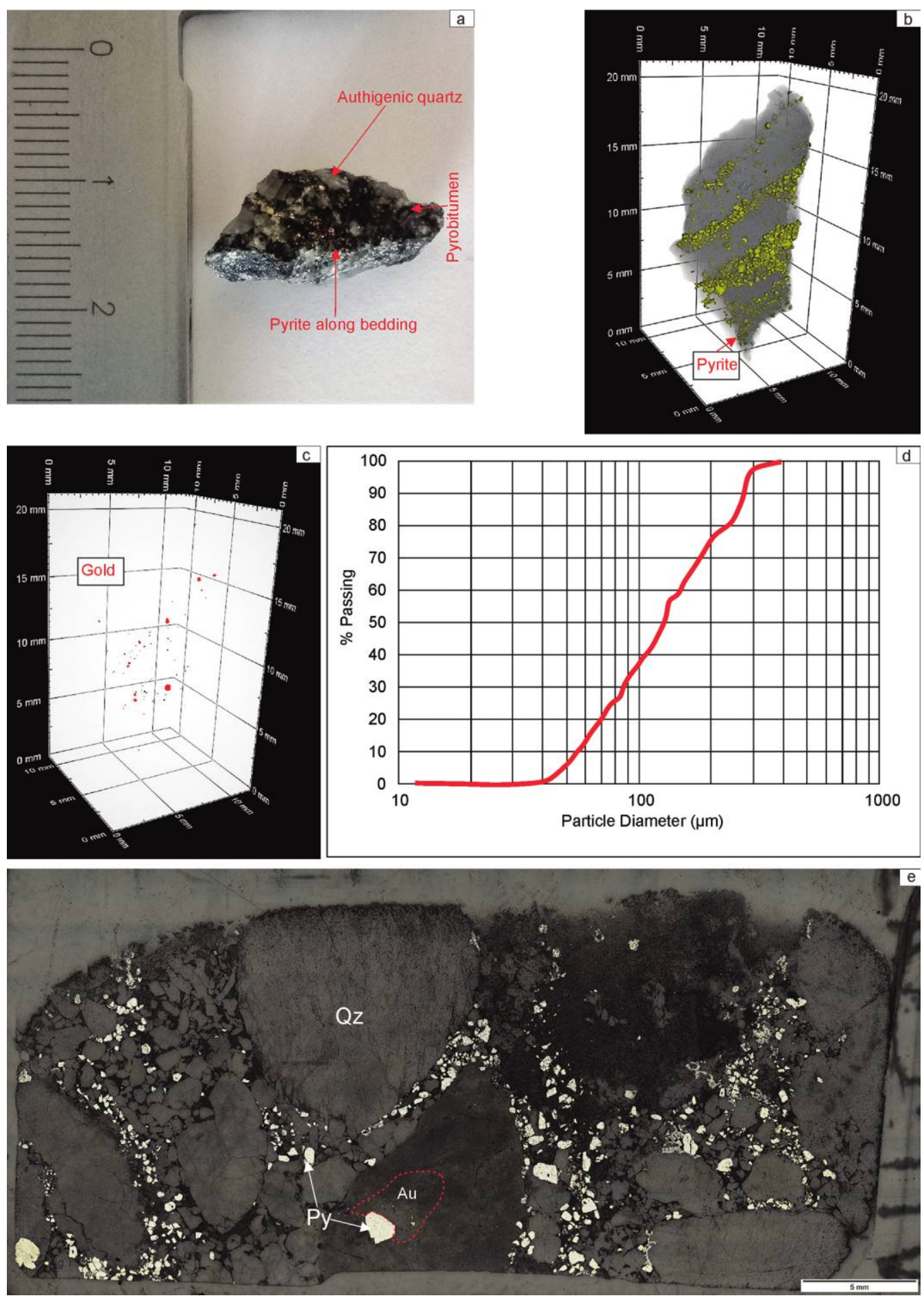

Figure 8. Microfocus X-ray computed tomography (micro-XCT) of Black Reef Formation conglomerate. $a$, Conglomerate specimen. $b$, Three-dimensional (3D) view of the specimen, showing pyrite distribution. $c$, 3D view of gold distribution in the specimen. $d$, Gold particle size distribution curve from micro-XCT. $e$, Reflected-light microscope image, showing the distribution of gold $(\mathrm{Au})$ and various pyrites (Py). Note the various class sizes of quartz (Qz) and associated microfractures. 
within the BRF conglomerate (fig. $8 \mathrm{c}$ ). Most of the gold particles are between $0.01 \mathrm{~mm}$ and $0.10 \mathrm{~m}$ in ECD (fig. 8d). Gold grains smaller than $0.002 \mathrm{~mm}$ were observed under reflected-light microscopy (fig. 8e). Gold occurs most often between or on the boundary of pyrite grains (fig. 8e). Gold and uranium occur together in the inclusion-bearing detrital pyrite and within the various pyrobitumen forms. Some of the gold occurs within quartz veins. Outside of the pyrobitumen nodules, $U$ minerals generally occur along the boundaries of pyrite. The gold and pyrite particles in the conglomerates are much larger than those in quartz arenite and shales. In most of the samples, uraninite and brannerite have microinclusions of pyrobitumen and a variety of minerals such as gold and sphalerite. The mineralogy of the quartz arenite samples is similar to that of the conglomerate. An XRD analysis of selected shale samples from the BRF indicates that the phyllosilicate minerals are mainly muscovite and chlorite. The mineralogical analyses revealed obvious qualitative differences in bulk mineral compositions among the shale samples (table A1). The mineralogical assemblages of the BRF are similar to those obtained by Phillips and Law (1994) and Alexandre et al. (2006) and represent typical low-grade metamorphic conditions.

Geochemistry. Major Elements. Major elements of clastic sedimentary rocks record factors on processes that influence the sediment, such as sorting and maturity (Taylor and McLennan 1985). Understanding these factors may provide insights into the nature of source terranes or the provenance of the BRF succession. The major-element oxide data for the BRF are presented in table S1. The results show that the BRF quartz arenite and conglomerate are slightly depleted in $\mathrm{TiO}_{2}$ and $\mathrm{Al}_{2} \mathrm{O}_{3}$, relative to PAAS (fig. $9 a, 9 b$ ). The $\mathrm{Fe}_{2} \mathrm{O}_{3}$ content of the $\mathrm{BRF}$ shale ranges from 1.07 to $6.97 \mathrm{wt} \%$, with $\bar{x}=2.68 \pm 2.34 \mathrm{wt} \%$. The $\mathrm{Fe}_{2} \mathrm{O}_{3}$ of the BRF quartz arenite ranges from 0.76 to $3.01 \mathrm{wt} \%(\bar{x}=1.56 \pm 0.75)$, whereas the conglomerates have $\mathrm{Fe}_{2} \mathrm{O}_{3}$ contents that range from 0.63 to $6.41 \mathrm{wt} \%(\bar{x}=2.66 \pm 1.43)$. Quartz arenite of the BRF contains 90.22-94.83 wt\% $\mathrm{SiO}_{2}$ $(\bar{x}=92.83 \pm 1.44)$ and $\mathrm{Al}_{2} \mathrm{O}_{3}$ between 2.35 and 5.93 $\mathrm{wt} \%(\bar{x}=3.56 \pm 1.05)$. The samples from the BRF conglomerate show a relatively wide compositional range, with $\mathrm{SiO}_{2}$ between 83.37 and $92.61 \mathrm{wt} \%$ $(\overline{\mathrm{X}}=87.69 \pm 2.74)$ and $\mathrm{Al}_{2} \mathrm{O}_{3}$ between 1.96 and $10.28 \mathrm{wt} \%(\bar{x}=5.35 \pm 2.17$; fig. $9 b)$. Shales of the BRF are dominated by $\mathrm{SiO}_{2}(61.19-82.21 \mathrm{wt} \% ; \bar{x}=$ $73.28 \pm 7.17)$ and $\mathrm{Al}_{2} \mathrm{O}_{3} \quad(8.99-17.83 \mathrm{wt} \% ; \bar{X}=$ $15.05 \pm 3.63)$. The $\mathrm{TiO}_{2}$ and $\mathrm{Al}_{2} \mathrm{O}_{3}$ contents of the BRF shales are similar to those of the PAAS reference (fig. 9c; Taylor and McLennan 1985).
The BRF rocks contain TOC that is mostly $<1 \mathrm{wt} \%$. On average, the BRF shales contain $0.99 \mathrm{wt} \%$ TOC, the quartz arenite contains $0.15 \mathrm{wt} \% \mathrm{TOC}$, and the conglomerate contains $0.21 \mathrm{wt} \%$ TOC. The TS content of the BRF is highly variable, ranging from 0.32 to $0.39 \mathrm{wt} \%(\bar{x}=0.35 \pm 0.03)$ in shales, from 0.14 to $1.73 \mathrm{wt} \%(\bar{x}=0.43 \pm 0.46)$ in quartz arenite, and from 0.10 to $4.38 \mathrm{wt} \%(\bar{x}=1.55 \pm 1.03)$ in the conglomerate. We observe a negative correlation between TOC and TS in the conglomerate $(r=-0.40)$, whereas the quartz arenite and shale display a weak positive correlation $(r=+0.24$ and +0.35 , respectively). A strong positive correlation is observed between TS and total Fe $(r=+0.95)$ in the conglomerate and a good positive correlation in the quartz arenite $(r=+0.54)$, indicating that these components are mainly located in pyrite. We also observe a positive correlation between $\mathrm{TOC}$ and $\mathrm{Al}_{2} \mathrm{O}_{3}$ in the shale samples $(r=+0.71)$ and conglomerate $(r=+0.35)$ and no correlation in the quartz arenite $(r=-0.18)$. Negative correlations between TOC and $\mathrm{SiO}_{2}$ and between TS and $\mathrm{SiO}_{2}$, are observed in all the BRF samples except the quartz arenite, where TOC correlates positively with $\mathrm{SiO}_{2}$.

Trace Elements. Certain trace elements, especially those that are relatively immobile in various environments, are regarded as robust indicators of source-rock composition (Taylor and McLennan 1985). The quartz arenite samples are enriched in large-ion lithophile elements (LILEs), such as $\mathrm{Rb}$, $\mathrm{Ba}, \mathrm{Sr}$, and $\mathrm{Cs}$, and transition metals (TMs), such as $\mathrm{Co}, \mathrm{Cr}$, and $\mathrm{Ni}$, when compared to PAAS (fig. 10a). Some of the quartz arenite samples show depletion in high-field-strength elements (HFSEs), such as $\mathrm{Nb}, \mathrm{Hf}, \mathrm{Th}$, and $\mathrm{U}$, relative to PAAS (fig. 10a). Comparison of the average trace-element values of the BRF shales and conglomerates with those of the PAAS reference indicates that the shales and conglomerates are relatively enriched in LILEs (fig. 10b, $10 c)$. The HFSEs, such as Nb, Hf, and $\mathrm{U}$, and TMs, such as $\mathrm{Co}, \mathrm{Cr}, \mathrm{Cu}$, and $\mathrm{Ni}$, are also enriched in the shale and conglomerate samples. In the BRF shales, most of the analyzed trace elements correlate positively with TOC, except for $\mathrm{Co}, \mathrm{Cu}$, and Ni. A strong positive correlation is observed between TS and Mo $(r=+0.87)$. Elements such as $\mathrm{Pb}, \mathrm{Co}, \mathrm{Cu}, \mathrm{Ni}$, and $\mathrm{Zn}$ correlate negatively with TOC in the conglomerate but correlate positively with TS, whereas Cs, Cr, V, Ga, Zr, Hf, Ti, Tl, and Mo display a positive correlation with TOC.

Figure 11 shows the PAAS-normalized REE patterns for all of the BRF samples from the Carletonville goldfield. The BRF shales have a higher total $\operatorname{REE}$ content $\left(\sum \mathrm{REE}=134.99 \mathrm{ppm}\right)$ when compared 


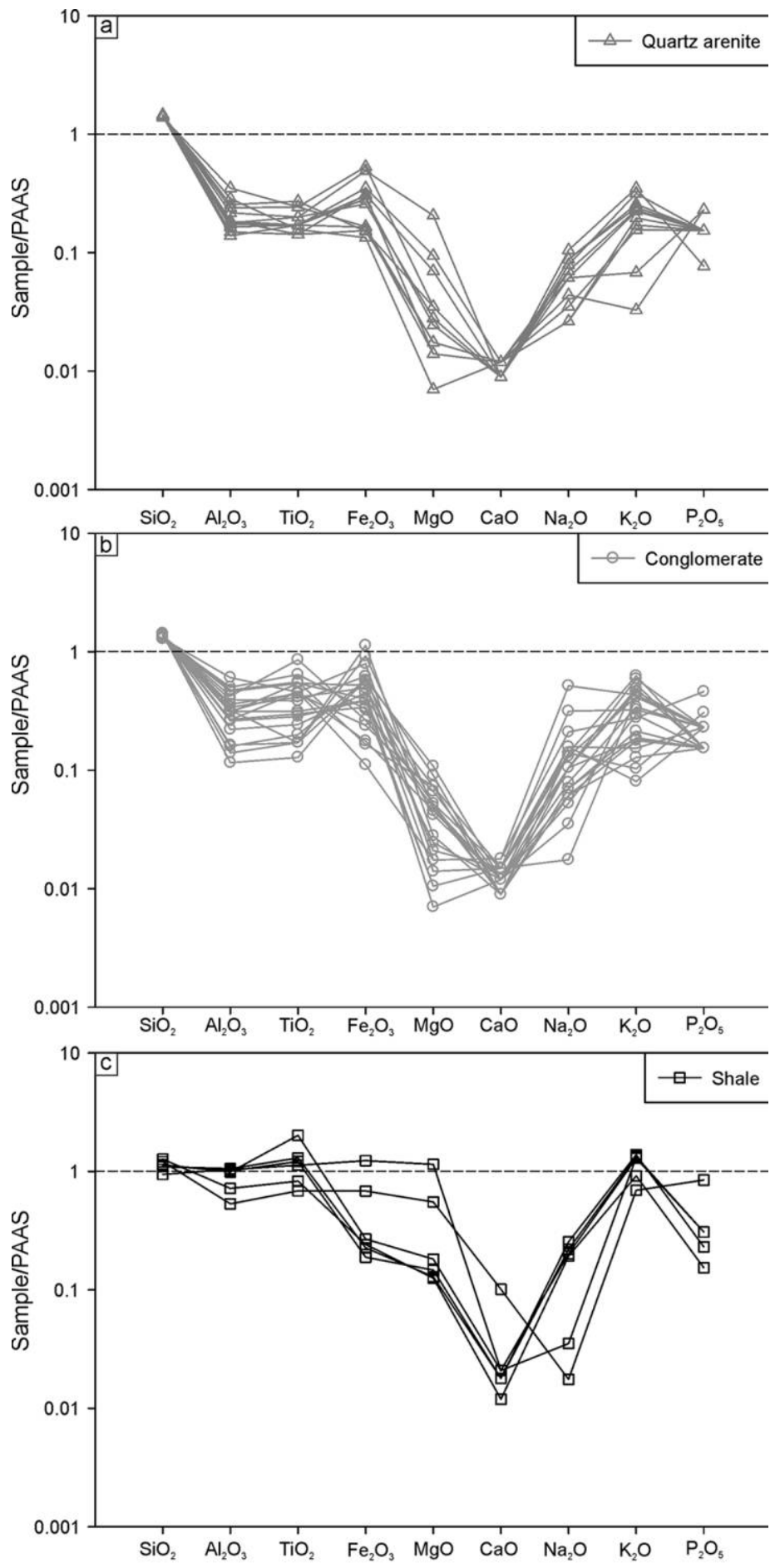

Figure 9. Multielement diagram of average major-element concentrations for Black Reef Formation lithology: quartz arenite $(a)$, conglomerate $(b)$, and shale $(c)$. Normalizing values are from Taylor and McLennan (1985). The dashed line indicates values where the sample concentration values are equal to post-Archean Australian shale (PAAS) reference values. A color version of this figure is available online. 

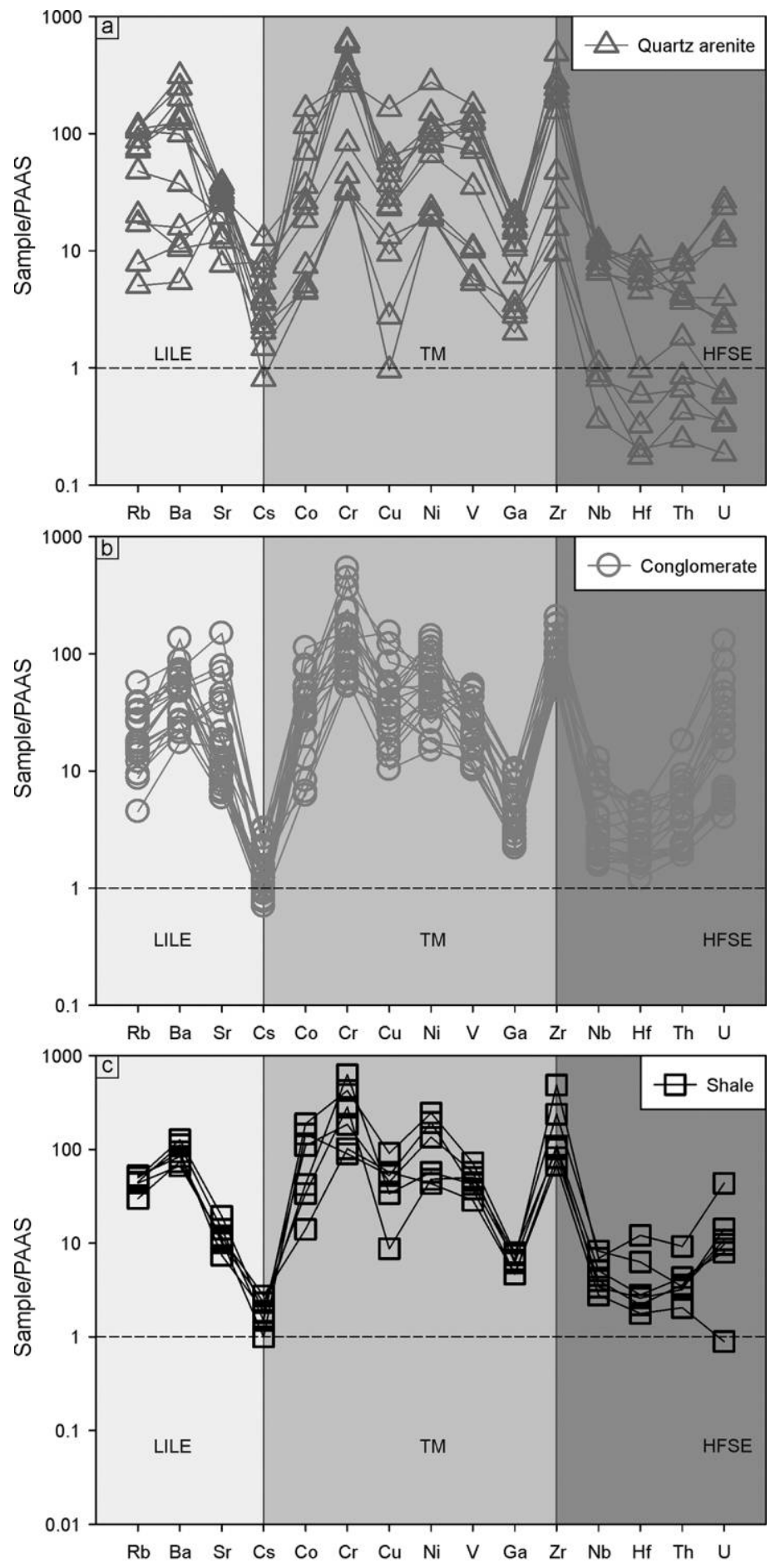

Figure 10. Multielement diagram of average trace-element concentrations for Black Reef Formation lithology: quartz arenite $(a)$, conglomerate $(b)$, and shale $(c)$. Normalizing values are from Taylor and McLennan (1985). The dashed line indicates values where the sample concentration values are equal to post-Archean Australian shale (PAAS) reference values. A color version of this figure is available online. 

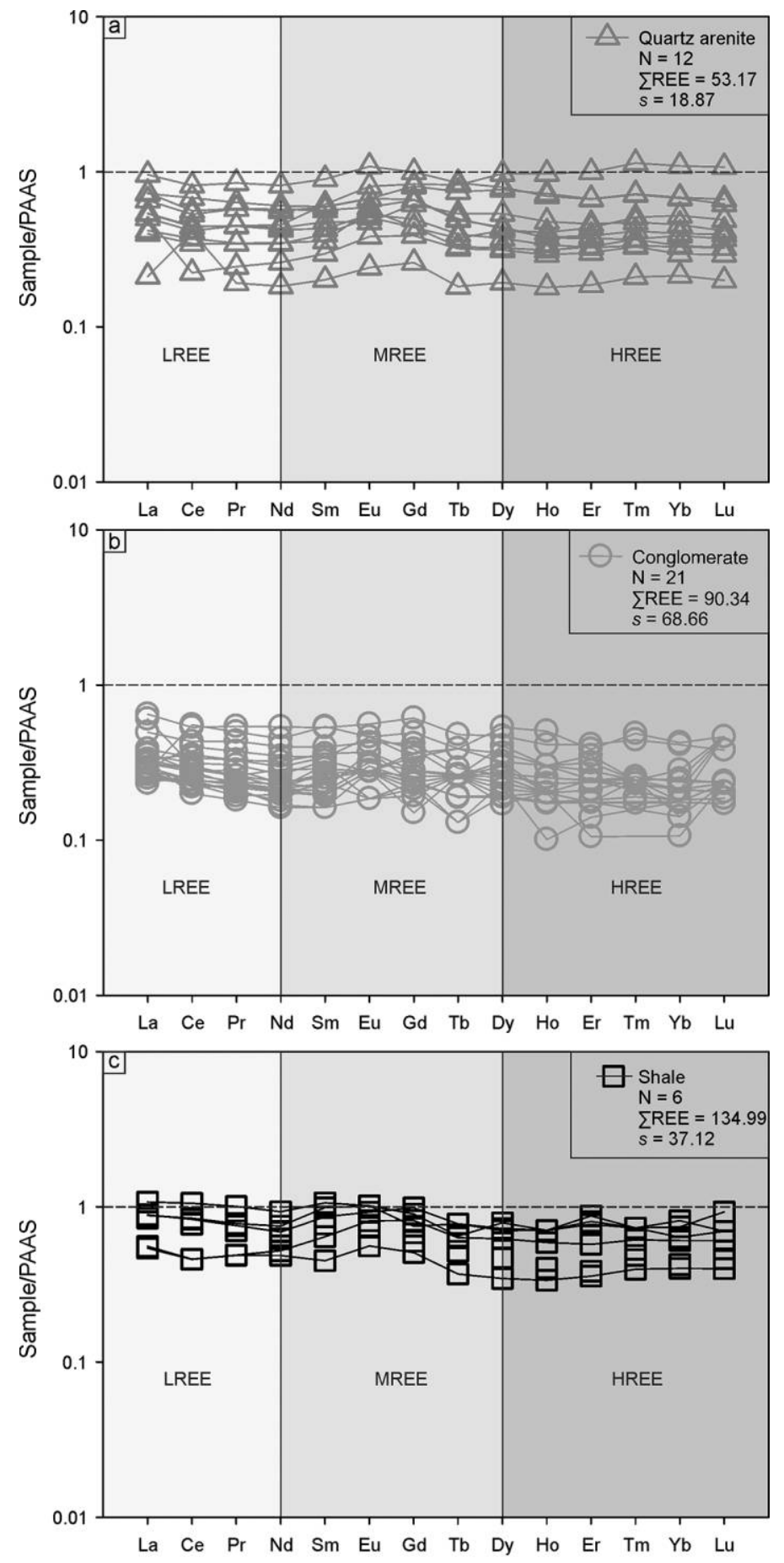

Figure 11. Rare earth element (REE) diagram for Black Reef Formation lithology: quartz arenite $(a)$, conglomerate (b), and shale (c). Light-REE (LREE), medium-REE (MREE), and heavy-REE (HREE) fields have been denoted by the gray areas. Normalizing values are from Taylor and McLennan (1985). The dashed line indicates values where the sample concentration values are equal to post-Archean Australian shale (PAAS) reference values. A color version of this figure is available online. 
to the quartz arenite $\left(\sum\right.$ REE $\left.=53.17 \mathrm{ppm}\right)$ and conglomerate $\left(\sum\right.$ REE $\left.=90.34 \mathrm{ppm}\right)$. Overall, the REE patterns are characterized by: (1) small light-REE (LREE)/heavy-REE (HREE) fractionation (conglomerate: $\mathrm{La}_{\mathrm{N}} / \mathrm{Yb}_{\mathrm{N}}=0.46-2.29$; quartz arenite: $\mathrm{La}_{\mathrm{N}} /$ $\mathrm{Yb}_{\mathrm{N}}=1.19-2.53 ; \quad$ shale: $\quad \mathrm{La}_{\mathrm{N}} / \mathrm{Yb}_{\mathrm{N}}=0.90-1.99 \mid$, (2) weakly sloping HREE profiles (conglomerate: $\mathrm{Gd}_{\mathrm{N}}$ / $\mathrm{Yb}_{\mathrm{N}}=0.77-2.60$; quartz arenite: $\mathrm{Gd}_{\mathrm{N}} / \mathrm{Yb}_{\mathrm{N}}=1.01-$ 2.22; shale: $\left.\mathrm{Gd}_{\mathrm{N}} / \mathrm{Yb}_{\mathrm{N}}=1.01-1.55\right)$, and (3) Eu anomalies of small amplitude (conglomerate: $\mathrm{Eu} / \mathrm{Eu}^{*}=$ 0.70-1.64; quartz arenite: $\mathrm{Eu} / \mathrm{Eu}^{*}=0.83-1.43$; shale: $\left.\mathrm{Eu} / \mathrm{Eu}^{*}=1.00-1.17\right)$. The BRF REE patterns are relatively similar to those in PAAS (Condie 1993). Quartz arenite and conglomerate have a low negative correlation with TOC, while shale correlates positively with TOC.

Correlation of Major and Trace Elements with Gold. A summary of major- and trace-element correlation with gold is presented in table $\mathrm{A} 2$. There is no direct correlation observed between gold and $\mathrm{SiO}_{2}$ in the shale samples $(r=-0.19)$. The quartz arenite samples show a negative correlation between Au and $\mathrm{SiO}_{2}(r=-0.53$; fig. 12a). The conglomerate samples show a positive correlation between $\mathrm{Au}$ and $\mathrm{SiO}_{2}$ $(r=+0.50)$. The quartz arenite samples display a weak positive correlation between TOC and Au $(r=+0.24)$ and a strong positive correlation between TS and Au $(r=+0.82$; fig. $12 b, 12 c)$. The conglomerate samples display a negative correlation between TOC and $\mathrm{Au}(r=-0.32)$ and a positive correlation between TS and Au $(r=+0.46)$. The shale samples show a negative correlation between TOC and Au $(r=-0.40)$ and a negative correlation between TS and $\mathrm{Au}(r=-0.56)$. Both quartz arenite and conglomerate samples show a positive correlation between $\mathrm{Au}$ and $\mathrm{U}$ - that is, correlation coefficients of +0.53 and +0.35 , respectively (fig. $12 d$ )—but the shale samples show a negative correlation $\mid r=$ $-0.63)$. In the shale and quartz arenite samples, $\mathrm{Zr}$ correlates positively with $\mathrm{Au}(r=+0.36$ and +0.53 , respectively), whereas in the conglomerate samples, $\mathrm{Zr}$ correlates negatively with $\mathrm{Au}(r=$ -0.17 ; fig. 12e). Summarily, all the BRF samples show a negative correlation between $\mathrm{Zr} / \mathrm{Ni}$ and $\mathrm{Au}$ (shale: $r=-0.43$; quartz arenite: $r=-0.43$; and conglomerate: $r=-0.34$; fig. 12f).

\section{Discussion}

Sediment History, Source, and Postdepositional Alteration. The chemical compositions of shale, quartz arenite, and conglomerate of the $\mathrm{BRF}$ are plotted as molar proportions within $\mathrm{Al}_{2} \mathrm{O}_{3}-\left(\mathrm{CaO}^{*}+\mathrm{Na}_{2} \mathrm{O}\right)-\mathrm{K}_{2} \mathrm{O}$ (A-CN-K) compositional space (Nesbitt 1992), where $\mathrm{CaO}^{*}$ represents $\mathrm{Ca}$ in silicate-bearing minerals only (fig. 13a). Most of the analyzed samples contain $\mathrm{K}_{2} \mathrm{O}$ contents that are comparable to those of the Witwatersrand rocks $\left(\mathrm{K}_{2} \mathrm{O}=0.1-1.4 \mathrm{wt} \%\right.$; Blane 2013). The chemical index of alteration (CIA) monitors the progressive alteration of plagioclase and potassium feldspars to clay minerals. The wide applicability of this index stems from the fact that feldspars are the dominant minerals of the upper crust (Nesbitt 1992). The CIA plot shows that the rate of paleoweathering in the source area was most likely moderate to high (fig. 13a). Most of the samples cluster in the muscovite theoretical field, with a trend toward the kaolinite field, indicating that the dominant silicate in the rock is muscovite /whether because of Kmetasomatism or because of the metamorphism of original illite in the sediment).

The high CIA values reflect the removal of labile cations $\left(\mathrm{Ca}^{2+}, \mathrm{Na}^{+}\right.$, and $\left.\mathrm{K}^{+}\right)$relative to the static residual constituents $\left(\mathrm{Al}^{3+}\right)$ during weathering. In the case of shales, the conversion of aluminous clay minerals, such as kaolinite, to illite by $\mathrm{K}$ addition results in a CIA value that represents the degree of $\mathrm{K}$ metasomatism. In the quartz arenite and conglomerate samples, K-metasomatism may not affect CIA values if it involves the replacement of plagioclase by $\mathrm{K}$-feldspar. However, no K-feldspar was observed in all the studied rocks. In this case, we suggest that the process may have involved mole-for-mole substitution of $\mathrm{K}$ for $\mathrm{Ca}$ or $\mathrm{Na}$ (Glazner 1988). The molar fractions in the ternary $\mathrm{Al}_{2} \mathrm{O}_{3}-\left(\mathrm{CaO}+\mathrm{NaO}+\mathrm{K}_{2} \mathrm{O}\right)$ $(\mathrm{FeO}+\mathrm{MgO})(\mathrm{A}-\mathrm{CNK}-\mathrm{FM})$ diagram show differences in clay mineral proportions, with the quartz arenite and conglomerate units grading from the chlorite to the smectite field, whereas the shales plot close to the muscovite field (fig. 13b). All of the studied samples have very low $\mathrm{CaO}(<0.35 \mathrm{wt} \%)$ and $\mathrm{Na}_{2} \mathrm{O}$ $(<0.6 \mathrm{wt} \%)$ concentrations, probably indicating the breakdown of plagioclase in the source region. The BRF shale is distinguished from the underlying Witwatersrand shales (Nwaila et al. 2017) particularly by its high $\mathrm{K} / \mathrm{Na}$ due to the possible addition of $\mathrm{K}$.

Elements such as $\mathrm{Al}, \mathrm{Ti}$, and $\mathrm{Zr}$ can be treated as essentially immobile elements because of the low solubility of the oxides and hydroxides of these elements in low-temperature aqueous solutions (Stumm and Morgan 1981; Ziemniak et al. 1993). Therefore, the $\mathrm{Al} / \mathrm{Ti} / \mathrm{Zr}$ ratios of sediments are generally very close to those of parental rocks. The $\mathrm{Al}_{2} \mathrm{O}_{3} / \mathrm{TiO}_{2}$ weight ratio is 23 for Archean komatiite, 15 for Archean basalt, 51 for Archean tonalite-trondhjemitegranodiorite, 59 for Archean granite, and 28 for Archean shale (fig. 14). In this study, the $\mathrm{Al}_{2} \mathrm{O}_{3} / \mathrm{TiO}_{2}$ values for shale are 11.8-22.2, those for quartz arenite are 21.5-43.9, and those for conglomerate are 11.945.4 (fig. 14a). This indicates that the BRF shales were 

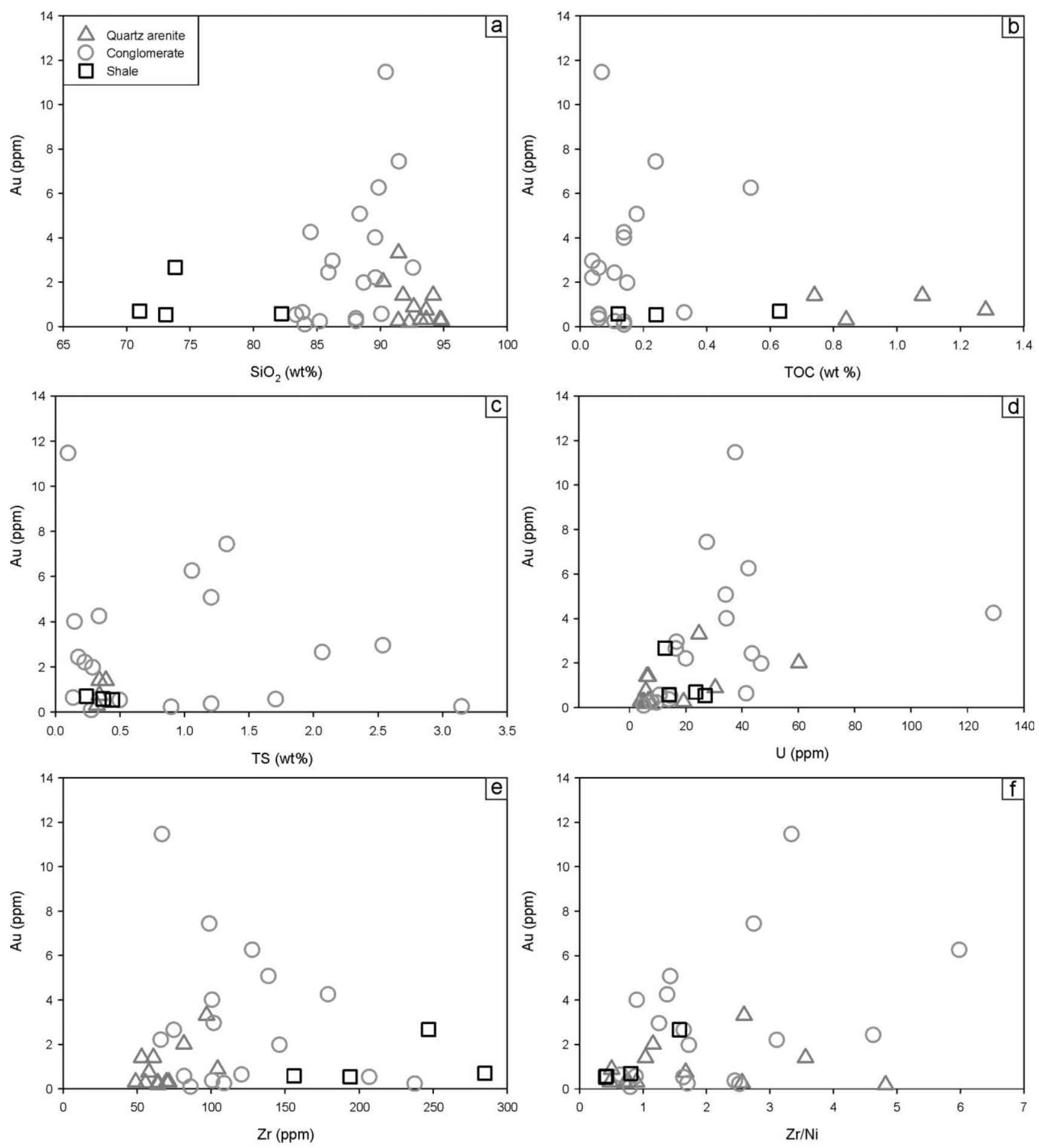

Figure 12. Correlation between gold and $\mathrm{SiO}_{2}(a)$, total organic carbon (TOC; $\left.b\right)$, total sulfur $(\mathrm{TS} ; c), \mathrm{U}(d), \mathrm{Zr}(e)$, and $\mathrm{Zr} / \mathrm{Ni}(f)$. Note positive correlations for the conglomerate units between $\mathrm{Au}$ and $\mathrm{SiO}_{2}$ and between $\mathrm{Au}$ and U. A color version of this figure is available online.

sourced from a mafic to intermediate source whereas the quartz arenite and conglomerate were sourced from a felsic-dominated source. The observed positive linear correlation between $\mathrm{Al}_{2} \mathrm{O}_{3}$ and $\mathrm{TiO}_{2}$ (shale: $r=+0.67$; quartz arenite: $r=+0.60$; conglomerate: $r=+0.74)$ suggests a variable sorting mechanism for the sampled units, reflecting temporal and spatial differences (fig. 14a). Furthermore, because of the 

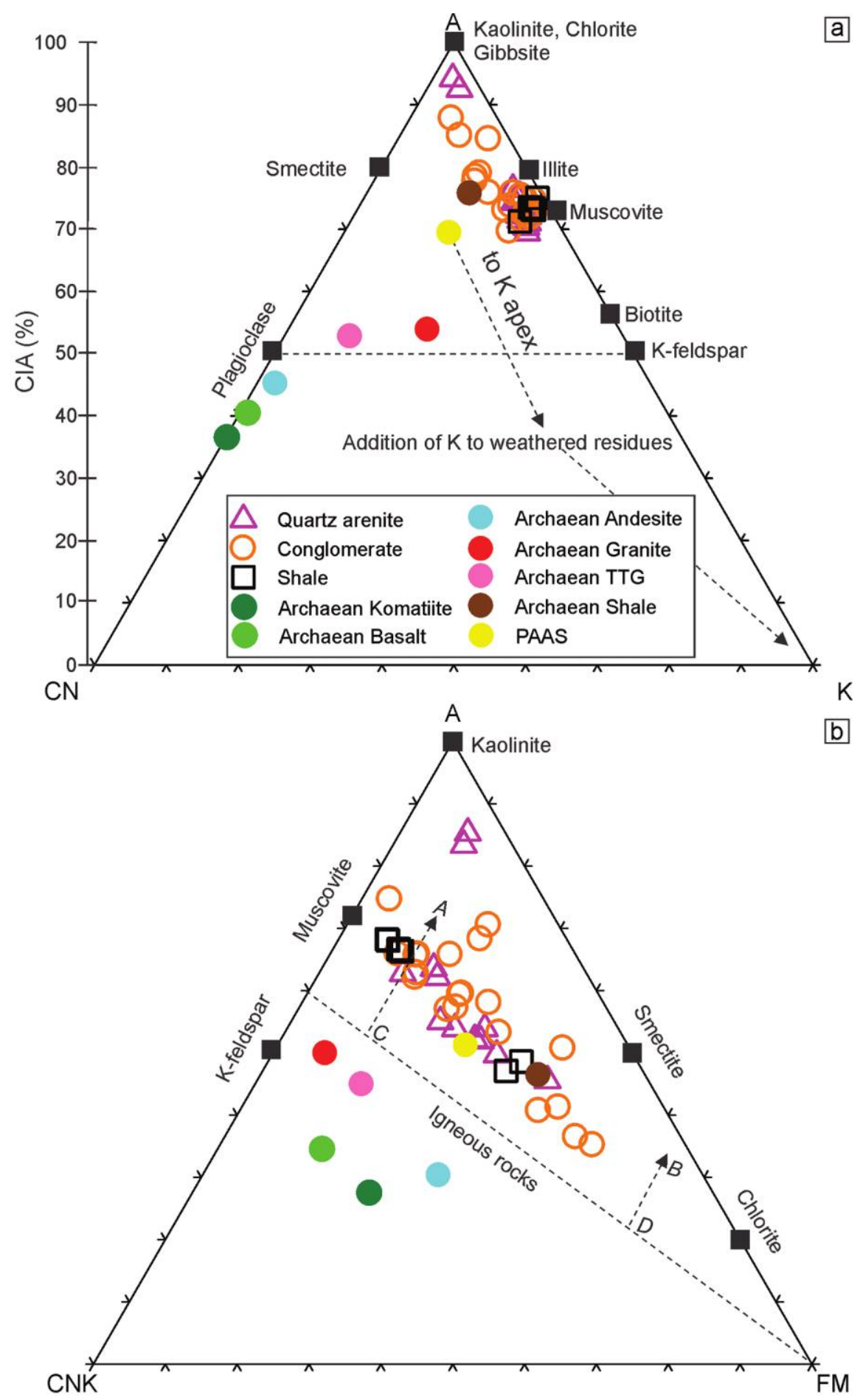

Figure 13. Extent of paleoweathering and postdepositional alteration in the Black Reef Formation. $a$, Chemical index of alteration (CIA) and ternary A-CN-K (molar fractions of $\left.\mathrm{Al}_{2} \mathrm{O}_{3}-\left(\mathrm{CaO}^{*}+\mathrm{Na}_{2} \mathrm{O}\right)-\mathrm{K}_{2} \mathrm{O}\right)$ diagram. $b$, Ternary A-CNKFM (molecular $\left.\mathrm{Al}_{2} \mathrm{O}_{3}-\left(\mathrm{CaO}+\mathrm{Na}_{2} \mathrm{O}+\mathrm{K}_{2} \mathrm{O}\right)-\left(\mathrm{FeO}_{(\mathrm{T})}+\mathrm{MgO}\right)\right)$ diagram showing weathering trends of granitic source (A) and basaltic source (B) according to Nesbitt and Young (1989). C indicates diagenetic and/or metasomatic transformation of kaolinite into illite with fluids characterized by high $\mathrm{K}^{+} / \mathrm{H}^{+}$ratios. $\mathrm{D}$ indicates diagenetic and/or metasomatic transformation of kaolinite into chlorite (Chl) with fluids characterized by high $\mathrm{Mg}^{2+}=\mathrm{H}^{+}$ratios; adapted from Camiré et al. (1993). PAAS = post-Archean Australian shale; TTG = tonalite-trondhjemite-granodiorite. 

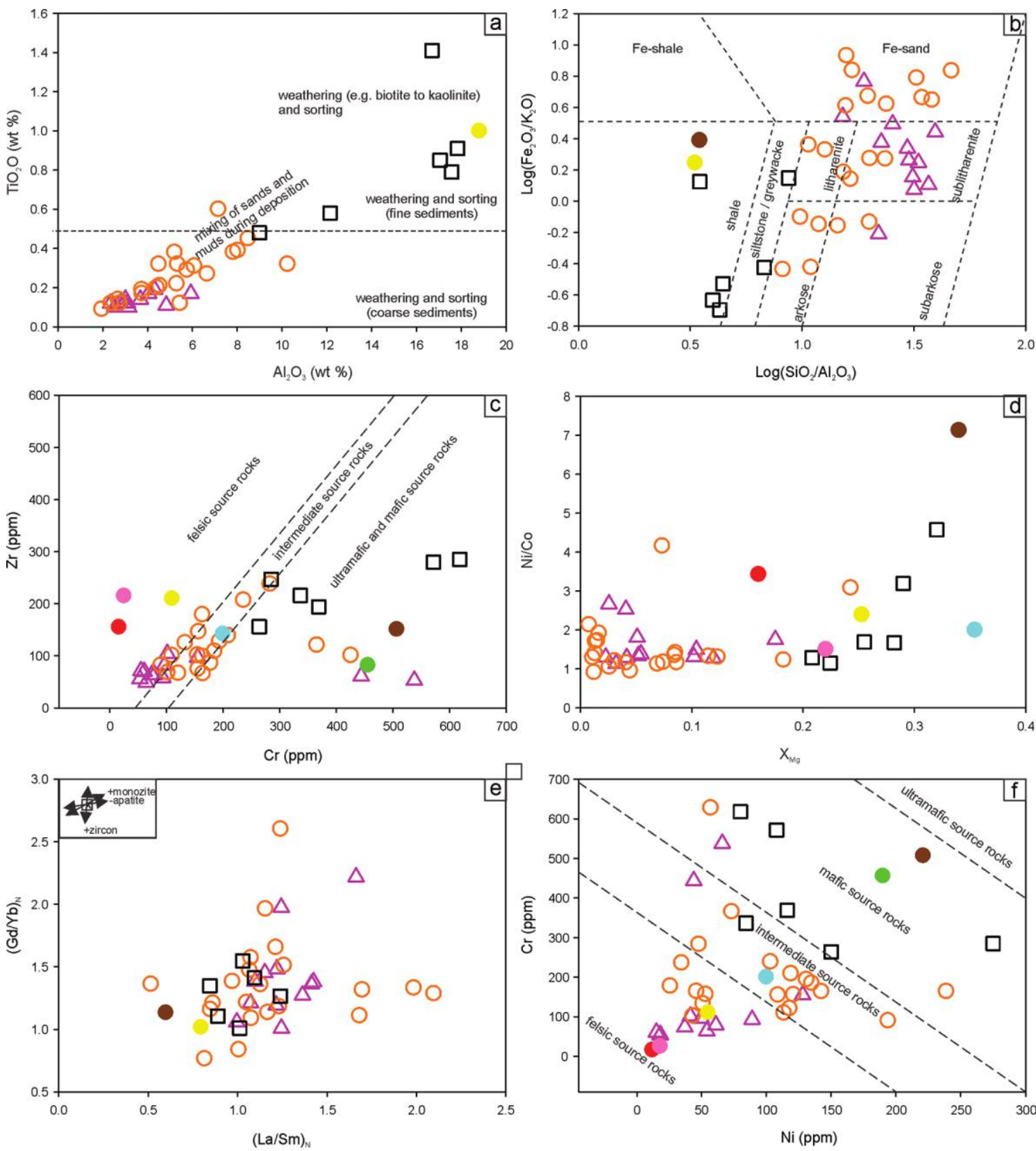

\begin{tabular}{|llll|}
\hline$\Delta$ & Quartz arenite & Archaean Andesite \\
$\bigcirc$ & Conglomerate & & Archaean Granite \\
$\square$ & Shale & & Archaean TTG \\
$\bigcirc$ & Archaean Komatiite & Archaean Shale \\
& Archaean Basalt & PAAS \\
\hline
\end{tabular}

Figure 14. Characterization of sediment provenance. $a$, Bivariate plot of $\mathrm{Al}_{2} \mathrm{O}_{3}\left(\mathrm{wt} \%\right.$ ) versus $\mathrm{TiO}_{2}(\mathrm{wt} \%)$ for the $\mathrm{Black}$ Reef. $b$, Logarithmic plot of $\mathrm{Fe}_{2} \mathrm{O}_{3} / \mathrm{K}_{2} \mathrm{O}$ versus $\mathrm{SiO}_{2} / \mathrm{Al}_{2} \mathrm{O}_{3}$. c , Cr content versus $\mathrm{Zr}$ content. $d$, $\mathrm{X}$ Mg versus Ni/Co. $e, \mathrm{Gd}_{\mathrm{N}} / \mathrm{Yb}_{\mathrm{N}}$ versus $\mathrm{La}_{\mathrm{N}} / \mathrm{Sm}_{\mathrm{N}}$. The effects of heavy-mineral sorting for apatite, monazite, and zircon $1-=1$ loss, $+=$ addition) are shown in the insert. $f$, Cr content versus Ni content. Data for Archean rocks reference samples are from Condie (1993). PAAS = post-Archean Australian shale; TTG = tonalite-trondhjemite-granodiorite. 
presence of interlayers within the shale, quartz arenite, and conglomerate, such as silt, organic matter and carbonates, the whole-rock composition does not exhibit typical characteristics, as shown in figure $14 b$.

Owing to the variably altered nature of the BRF rocks, trace elements that are considered to remain immobile during hydrothermal processes are used for further interpretations. Sedimentary sorting and provenance become detectable when Cr content is plotted against $\mathrm{Zr}$ content (fig. 14c). The $\mathrm{Zr} / \mathrm{Cr}$ ratios of the conglomerate and shale samples are positively correlated $(r=+0.77$ and +0.81 , respectively), suggesting an accumulation caused by particle-size selection during transport to the depositional area. The shale samples show relatively high $\mathrm{Zr}(156-285 \mathrm{ppm})$ and $\mathrm{Cr}$ (264-618 ppm) concentrations, interpreted in this study to represent a source from both mafic and felsic rocks (fig. 14c). The quartz arenite and conglomerate have $\mathrm{Zr}$ concentrations of 49.0-104.4 and 66.1-487 ppm, respectively, and Cr concentrations of 52.8-538 and 90.0-627.8 ppm, respectively. Mafic volcanic rocks of the Ventersdorp Supergroup and greenstone rocks are the more suitable source-rock candidates for the elevated $\mathrm{Cr}$ in the shales, whereas siliciclastic sedimentary rocks of the Witwatersrand Supergroup and felsic rocks are the most suitable candidates for the elevated $\mathrm{Zr}$ content. The most likely source rocks of the BRF, quartz arenite, and conglomerate are the clastic rocks of the Witwatersrand Supergroup and various Archean felsic rocks.

The different source-rock compositional contents of BRF rocks are also illustrated in fig. $14 d$ by plotting $\mathrm{Ni} / \mathrm{Co}$ ratio versus magnesium number $\left(\mathrm{X}_{\mathrm{Mg}}\right)$. A plot of the $\mathrm{Gd}_{\mathrm{N}} / \mathrm{Yb}_{\mathrm{N}}$ ratio against the $\mathrm{La}_{\mathrm{N}} / \mathrm{Sm}_{\mathrm{N}}$ ratio (fig. 14e), in which " $\mathrm{N}$ " indicates PAAS-normalized values, shows a scatter for all the BRF samples. This agrees with figure 14f, which indicates that the BRF sediments come from mixed sources with elevated $\mathrm{Ni}$ and $\mathrm{Cr}$ concentrations indicating mafic/ultramafic input, whereas elevated $\mathrm{Zr}$ content suggests a more felsic input. In the PAAS-normalized traceelement plots for the BRF, the quartz arenite and conglomerate have lower trace-element abundances when compared to the shales, owing to quartz dilution in the former associated with sorting effects.

Relative Timing of Gold Mineralization. Detrital mineralogy and clast assemblage, complemented by whole-rock major- and trace-element geochemistry, provide major constraints on both the nature and the provenance of the putative protoliths for the BRF rocks. The rock types of the BRF have variable mineralogy and major- and trace-element geochemistry, influenced to a large extent by postdepositional alteration. Underground mapping and high-resolution 3D seismic imaging (see "Geological Mapping and
3D Reflection Seismic Imaging" above; figs. 2-5) show that the BRF is characterized by a series of faults and fractures. Fractures in the reef zone are associated with localized faulting on a millimeter scale. We assume that the large native gold particles in such stratigraphic positions indicate short-range remobilization and precipitation of gold in the presence of reductants (such as sulfidic minerals). Gold content in the BRF conglomerate, where it truncates the Witwatersrand reefs and the VCR, is $>5 \mathrm{~g} \mathrm{t}^{-1}$. It is interesting to note that the quartz veins that occupy tectonic contacts between the underlying strata and the BRF reef zone have the highest Au content $\left(\sim 200 \mathrm{~g} \mathrm{t}^{-1}\right.$; fig. $\left.2 c\right)$. The well-mineralized zones are characterized by the presence of pyrite and pyrobitumen, with complex textures containing inclusions of native gold.

The BRF is affected by various metamorphic events. The first metamorphic event is ascribed to loading of the basin during emplacement of the ca. $2.100 \mathrm{Ga}$ Pretoria Group (Eriksson et al. 2006), whereas the second event took place $\sim 45$ My later and is related to the intrusion of the $2.055 \mathrm{Ga}$ Bushveld Igneous Complex (Zeh et al. 2015). The third event took place $\sim 77 \mathrm{My}$ later and is ascribed to the $2.023 \mathrm{Ga}$ Vredefort meteorite impact (Kamo et al. 1996). Robb et al. (1997) suggested that the timing of oil entrapment in the reefs can be estimated more definitively because the host pyrobitumen nodules contain secondary uraninite. However, this is highly contested because the U-Pb decay system was partially open (Zartman and Frimmel 1999). Throughout opensystem conditions, the fluid flow must have been pervasive, allowing an isotopic homogenization of all interacted rocks by convective circulation during the regional metamorphism. The 3D seismic data suggest that the major reverse and duplex faulting formed after the BRF and Pretoria Group times; that is, faults breach and crosscut both the BRF and the Pretoria Group strata (see fig. $4 b, 4 c$ ). Gold in tectonic contacts between the BRF and underlying reefs is associated with lateral displacement structures that are earlier than the normal faults. Much of the organic material separating conglomerate bands of the BRF is intrinsic to the sedimentary beds, particularly the partings within the shale and intercalation with siltstone. The widespread fracture-filling pyrobitumen and nodules indicate possibly short travel distances. The deposition of the BRF predates the $2.06 \mathrm{Ga}$ Bushveld igneous event within the Kaapvaal Craton, where a series of initial rhyolitic extrusive rocks were followed by large-scale magmatism (Buick et al. 2001). Magmatic underplating and intrusion of large amounts of melts into the lower to middle crust during the emplacement of the Bushveld 
Complex led to a notable thermal metamorphism and metasomatism in the BRF and other units of the Transvaal and Witwatersrand Supergroups (Frimmel and Minter 2002; Bose et al. 2012). This tectonicthermal event significantly affected the central parts of the Transvaal Supergroup, as evident from the Transvaal Supergroup rocks that have subsided beneath the intruding Bushveld magmas.

Approximately 32 My after the Bushveld event, the distinct $2.023 \mathrm{Ga}$ (Kamo et al. 1996) Vredefort impact left a major imprint on the structural and thermal evolution of the Witwatersrand Basin. We suggest that the Vredefort meteorite impact caused secondary permeability and reactivated preexisting structures in the Transvaal, Ventersdorp, and Witwatersrand Supergroups, which allowed remobilization of gold and other ore constituents (Gibson et al. 1998; Frimmel et al. 1999). New faults with south-down throws were also formed. This is supported by the structural linkage between Transvaal, Ventersdorp, and Witwatersrand strata observed from the seismic sections (figs. 4, 5). Complex fault systems associated with the Vredefort impact event have been observed in the Witwatersrand Basin goldfields on the outer limb of the Carletonville goldfield and the Potchefstroom synclinorium west of Johannesburg (Killick 1993; Trieloff et al. 1994). We suggest that these structures are the main conduits responsible for dispersion of gold into distal areas of the BRF. Impact-related shock or basin dewatering created conditions for metal precipitation, and fluids became the driving force for gold accumulation along the reactivated and newly created microfractures. Quartz veins were also formed during this stage (Hayward et al. 2005), with some of them hosting gold, as evident from the localized gold enrichment within quartz veins. Preliminary Re-Os analyses of three different pyrite morphologies yield Re-Os model ages of approximately $3.2 \mathrm{Ga}$ (subrounded compact pyrite), 3.1 Ga (rounded/massive microcrystalline pyrite), and $2.0 \mathrm{Ga}$ (euhedral/hydrothermal pyrite), with Re/Os ratios and Os concentrations similar to those of the Witwatersrand compact rounded, rounded/massive microcrystalline and euhedral pyrite of the Vaal, Steyn, and VCR reefs, respectively (fig. S1 [data other than BRF from Kirk 2004], available online; table A4). This overlaps previously obtained ages for the reefs of the Witwatersrand and Ventersdorp Supergroups, indicating that the main hydrothermal event may have occurred around $2.0 \mathrm{Ga}$.

Metallogenic Model. Metallogeny of the Black Reef has been a subject of considerable research attention, which essentially has revolved around the question of whether gold mineralization is related to reworking of the Witwatersrand reefs (Frankel 1940; Germs 1982; Spellman 1986) or to postdepositional hydrothermal alteration (Barton and Hallbauer 1996; Frey 1988; Fuchs et al. 2016). Any model used to explain the gold metallogeny in the BRF must account for the fundamental nature of the source, primary controls on gold distribution, and aspects of postdepositional alteration. The BRF gold is hosted by conglomerates, and the morphology of the gold that is now preserved is typical of postdepositional precipitation. Previous researchers have not fully addressed the aspects of sediment provenance and sedimentological control on gold grade, and the significance of postdepositional microfractures has been underrepresented or undersupported in the literature.

The majority of previous research on the BRF gold deposit focused on the East Rand goldfield, because (1) it contains economic concentrations of gold, (2) it has the best surface exposures of the BRF sedimentary facies, (3) it comprises large pyrite nodules reaching up to $5 \mathrm{~mm}$ in diameter, and (4) samples are accessible near the surface, with the BRF/Kimberley Reef subcrop (Henry and Master 2008; Hofmann et al. 2009; Fuchs et al. 2016). The size of the pyrites, together with their isotopic composition (Barton and Hallbauer 1996; Hofmann et al. 2009) in the East Rand goldfield, has been used to suggest that the pyrite was not derived from underlying Witwatersrand reefs (Fuchs et al. 2016). In the West Rand goldfields, selective mining of the Black Reef (i.e., Cooke and Kloof sections in the Western Areas goldfield and Lindum reefs in the Krugersdorp goldfield) has led to limited exposures of the BRF; thus, not much academic research could be conducted.

Recent BRF mining in the Carletonville goldfield has presented an opportunity to study the BRF in areas that were previously unexplored. Unlike in the East Rand goldfield, where localized BRF gold enrichments are associated with deep erosion of the paleotopographic surface, with paleochannels deeply incising the underlying Kimberley Reef (Barton and Hallbauer 1996), the BRF in the West Rand goldfields (e.g., Carletonville goldfield) have shallow basal degradation surfaces truncating both the Witwatersrand reefs and the VCR. Much of the Black Reef paleotopographic surface is relatively flat, although localized undulations are common, especially closer to geological structures such as folds and synclines. In addition, the sizes of pyrite grains $(10-1800 \mu \mathrm{m}$ in ECD) found in the BRF at the Carletonville goldfield are similar to those observed in the immediately underlying reefs (Tibane 2013). The compositional heterogeneity of pyrite grains (i.e., syngenetic and epigenetic pyrite generations) is similar to those ob- 
served in the Witwatersrand Supergroup (Koglin et al. 2010; Agangi et al. 2015). It is also significant that sediment provenance and the occurrence of gold from this study show the following: (1) sediments were sourced from a mafic to felsic source; (2) gold occurs inside detrital pyrite and only adjacent to epigenetic pyrite; (3) microfractures are filled with either gold or pyrobitumen; (4) no evidence has been found for gold mineralization in most of the crosscutting structures, except in minor faults that filled with late-stage quartz veins; and (5) potassic alteration is common throughout the BRF.

A model that achieves the demands above can be found by examining the gold grade in the reef zone (ca. $4.1 \mathrm{~g} \mathrm{t}^{-1}$ ) and the country rocks (quartz arenite [ca. $1.3 \mathrm{~g} \mathrm{t}^{-1}$ ] and shale [ca. $\left.\left.1.1 \mathrm{~g} \mathrm{t}^{-1}\right]\right)$, together with potential fluid conduits (faults). The spatial association of gold and detrital pyrite, along with a subcrop position in the Carletonville goldfield, provides some of the most concrete evidence to date in favor of mechanical recycling of the underlying reefs, while fracture-filling gold with pyrobitumen indicates short-range remobilization of gold by migrating hydrothermal and hydrocarbon fluids. The introduction and subsequent remobilization of gold in the BRF can be interpreted to be linked to the presence of pyrite and a series of microscale fractures that acted as fluid conduits. The BRF is surrounded by several greenstone belts, of which some (e.g., Barberton, Murchison, Giyani, and Kraaipan) contain abundant gold. These greenstone belts, in light of their age $(>2.7 \mathrm{Ga})$, would make the most likely sources of sediments including gold. The instinctive conclusion would be that the basal conglomerate of the BRF was sourced from gold-enriched, greenstonedominated hinterlands, whereas the country rocks were sourced from barren hinterlands. These would make a strong match to the sediment provenance obtained in this study and the provenance of pyrite as observed by Fuchs et al. (2016). However, the postulated gold-enriched greenstone-dominated hinterland at the time of BRF deposition contradicts the actual spatial distribution of the gold in the BRF as well as the available sedimentological and field data. The BRF in the Barberton area, for example, is barren of gold. The BRF conglomerates are thick only where they truncate the underlying reefs, and there is a significant decrease in thickness of the conglomerates away from the subcrop positions, indicating that underlying reefs contributed much of the material to the BRF.

The second likely metallogenic model in the Black Reef involves the postdepositional introduction of gold, as suggested by Fuchs et al. (2016). Several factors contradict this purely epigenetic model or any other form of postdepositional introduction of gold and other critical ore constituents (table A3). The BRF has been affected by significant postdepositional alteration, which possibly included K-metasomatism. Potassic alteration was quite pervasive in the BRF and underlying strata and predates Vredefort-related alterations such as chloritization and formation of pseudotachylite (Frimmel and Gartz 1997). Provided that the large amount of aqueous-fluid ingress is solely responsible for the introduction of gold in the BRF, one would expect elevated gold concentrations away from the subcrop positions, especially where fault planes cut across both the BRF and the underlying strata. This is contradicted by a notable decrease in gold grade, which is directly proportional to the decreases in the conglomerate thickness away from the subcrop positions. The conglomerates are also either poorly developed or absent where there is no influence of the underlying strata (e.g., the Barberton area).

The lack of correlation between fluid ingress and gold mineralization shows that gold mineralization in the BRF is independent of both fluid amount and chemistry. The BRF and the Witwatersrand Supergroup most likely experienced relatively similar metamorphic overprinting with regard to the Vredefort meteorite impact-induced metamorphism, except that its stratigraphic position may have led to the intensely localized fracturing and voluminous fluid mobility. In addition, it is important to observe the strong sedimentological controls on the gold grade of the Black Reef, especially the causal relationship between gold and sedimentological parameters (i.e., clast assemblage, percentage conglomerate, and percentage detrital pyrite). This relationship is similar to the one suggested by Minter and Loen (1991), who postulated, using the three common characteristics of paleoplacer gold depots, (1) that the lateral extent of mature quartz arenite on unconformities generally exceeds $200 \mathrm{~km}^{2}$, indicating widespread erosion; (2) that topographic relief allows continuous reworking of sediments; and (3) the stratigraphic position of placer sediments, where stratigraphic stacking of placer events demonstrates degradation/aggradation cycles representing intermittent tectonic rejuvenation of the basin margin. In mesothermal-type gold deposits such as those in the Barberton greenstone belt, which are strongly controlled by shear zones, synthetic faults and microfractures tend to be orientated in the direction of the main shear zone. Not only do the subordinate geological structures follow this trend, but gold mineralization in such places is also channeled in permeable areas surrounding the main shear zone. However, evidence from underground geological mapping, orientation of the Black Reef ore 
body, and 3D reflection seismic data does not point to directional permeability of gold-bearing fluids that are related or channeled along dilatant zones (Sibson and Scott 1998). This is unlike structurally controlled gold deposits in the Transvaal Supergroup found in the Elandshoogte Mine in the Sabie-Pilgrim's Rest goldfield. The Sabie-Pilgrim's Rest deposits share many characteristics with those of Telfer, Western Australia, such as strata-bound quartz-sulfide-gold veins and gold mineralization linked to beddingparallel thrust faulting within the sedimentary pile (Harley and Charlesworth 1994).

We therefore propose that gold deposition occurred in two stages. Stage one of the mineralization process involved mechanical recycling of the underlying reefs, which is evident from the spatial relationship between gold grade and gold's proximity to the Witwatersrand reefs and the VCR in the Carletonville goldfield (table A3). Apart from the gold in late-stage quartz veins, the primary controls of gold grade are sedimentological parameters such as favorable lithology (conglomerates), percentage conglomerate, matrix assemblage, sorting, nature of basal contact, and percentage pyrite. It may not be a coincidence that the occurrence of BRF gold is strata bound and that both the overlying and underlying lithology contain very low gold concentrations $\left(<2 \mathrm{~g} \mathrm{t}^{-1}\right)$, with millimeter-scale dispersions. There is no correlation between the gold-rich conglomerate along the subcrop and preexisting structures that were formed before the deposition of the BRF, except for the scoured paleotopographic surface.

The BRF dips gently and is laterally very extensive, with no known mineralization that cuts across the stratigraphy outside of the basal conglomerate. This shows that some of the gold is a product of mechanical reworking of the underlying strata. With the exception of Vredefort meteorite impact-induced fractures, the major faults that crosscut the BRF are barren of gold. Much of the BRF gold is concentrated in the matrix of oligomictic conglomerates, cross beds, and scour surfaces within fluvial channels that truncates the underlying reefs. The mechanical recycling of Archean gold in sedimentary rocks has been noted in the gold deposits of the Witwatersrand reefs (Frimmel 2018) and in post-Archean gold deposits (i.e., Huronian gold deposits in Canada) because of truncation and reworking of underlying stratigraphically older units (Whymark and Frimmel 2018). It is envisaged that mechanical reworking released gold particles from the underlying reefs, which were then concentrated in the BRF along subcrop positions. The distribution of gold and the thickness of conglomerates forming during periodic mechani- cal recycling would, therefore, depend on the presence or absence of gold in the underlying reefs and the topographic relief that allows continuous reworking of sediments. Consequently, we argue that gold in the BRF, similar to that in the Witwatersrand Reefs, formed via mechanical recycling of gold from underlying strata followed by local chemical mobilization.

The second stage, involving chemical mobilization, led to a short-range (micrometer- to meterscale) mobilization of gold and other ore constituents. Remobilization that occurred within the Black Reef (micrometer-scale) and the VCR/Witwatersrand reefs is the most likely source of meter-scale mobilized gold into the Black Reef. On a goldfield scale, the western part of the BRF surface in the Carletonville goldfield is dominated by north-northeast-trending normal and thrust faults, while the eastern part is dominated by northwest-trending and minor northeast-trending normal and thrust faults (fig. 4). Many of these faults and duplexes and their related drag folds and horst-and-graben architectures are large enough to be visible on seismic sections (fig. 4). In seismic sections, the data also show that the Black Reef is deformed by a north-trending, upright, tight to open anticline, the crest of which is dissected by a series of west-dipping reverse faults and normal faults (fig. 4). The wavelength of the anticline is greater than $4 \mathrm{~km}$, and the amplitude is greater than $500 \mathrm{~m}$. In general, these faults exhibit variable dips and throws and offset the strata of the Pretoria Group as well as the BRF. The anticline represents an area where the Ventersdorp Supergroup has been eroded and the Black Reef unconformably overlies the Central Rand Group of the Witwatersrand Supergroup (fig. 4c).

Seismic imaging of the anticline and horsts is particularly interesting because they bring the Black Reef to near-surface, minable depths. Although the major faults crosscutting the BRF are usually barren of gold, the Vredefort meteorite impact triggered gold transport through induced fracturing and infiltration of meteoric water, followed by rapid uplift. Manzi et al. (2013) suggested that bedding-parallel fluid flow into low-displacement thrust systems in the VCR occurred because of induced fracturing and facilitated local mobilization of ore within and close to reefs. In the BRF, similar structures are common (figs. 4, 5) and are often accompanied by localized postdepositional alteration. However, it is only the microscopic fractures that often contain gold, such as fractured quartz pebbles and pyrite (fig. 6). The textures observed in the detrital pyrite can be explained by sedimentary processes such as mechanical abrasion (Koglin et al. 2010; da Costa et al. 2017). The epigenetic pyrite offers evidence of the postdepositional local sourcing and precipitation of gold and 
other ore constituents from the pyrite formation and breakdown process. The morphology of the BRF gold particles is more heterogeneous, reflecting the intensity of widespread postdepositional fluid migration and subsequent precipitation of native gold. The BRF gold morphology contrasts to that of the Witwatersrand reefs, where likely some of original detrital gold morphology is still preserved in the form of toroidal/peened gold (Minter 1999). The distal areas (with respect to the subcrop positions) in the BRF could have been starved of gold-bearing fluids because of their position in portions of the basin relative to the underlying reefs. Another reason could be that the chemical components of the postdepositional fluids were too diluted to form an ore-grade deposit away from the subcrop positions. Pyrite and pyrobitumen played a critical role during postdepositional remobilization of gold, as suggested by Fuchs et al. (2016). Fractures in both pyrite and quartz acted as trap sites for gold precipitation. There is strong evidence of hydrocarbon mobility during subsequent fracturing and gold mineralization. Postdepositional fluid infiltration triggered partial dissolution and reprecipitation of gold and other ore constituents and thus led to the observed late paragenetic textural position of the gold that is commonly observed in the BRF (Frey et al. 1991; Gauert et al. 2010). This is attested to by the association of gold-pyrite-pyrobitumen and microfracture networks in the studied samples. Fluids important for localized gold remobilization were most likely introduced to the BRF at the Carletonville goldfield along predominantly northeast-striking feeder conduits, as evidenced by the northwest-to-southeast decline in total gold content. This mechanism explains both primary accumulations of gold - including postdepositional alteration, the geometrical relationship between gold, and geological structures - and the occurrence of native gold on a variety of scales. As in many paleoplacer gold deposits, it is difficult to establish the morphology of the original gold grains.

\section{Conclusions}

The gold-bearing conglomerates of the BRF decrease in thickness and gold grade away from the subcrop positions. The underlying VCR and Witwatersrand reefs contributed the bulk of conglomeratic material, including gold, pyrite, and quartz. The occurrence of gold in the BRF can be explained by a mechanical process followed by postdepositional remobilization. Not only was gold distribution controlled by sedimentary processes such as mechanical reworking, but at least some of it was due to the intense circulation of aqueous hydrothermal and hydrocarbon fluids that migrated through newly formed and reactivated structures. Postdepositional fractures in the BRF facilitated fluid movement. The local enrichment of gold within the quartz veins indicates that the fluids responsible for gold and quartz deposition moved through the fractures. Postdepositional accumulation and precipitation of native gold were facilitated by the presence of fracture networks, pyrobitumen, and pyrite. Postdepositional alteration also led to gold dispersion within 1-2 $\mathrm{m}$ of minor faults. Insufficient data exist to determine the extent of the formation of macro- and microscale fluid conduits. This determination requires further macroand microstructural analysis, coupled with fluid inclusion studies and direct dating of mineralization, as it could provide insights into the structural paragenesis, extent, and the absolute age of gold mineralization in the BRF. Although the BRF is much younger and less endowed, when compared to the Witwatersrand reefs and the VCR, its metallogeny provides important information on the gold mineralizing processes that took place during the Archean and Paleoproterozoic times. This supports the notion that Witwatersrand-type mineralization was not limited to the Mesoarchean but was repeated for several millions of years into Paleoproterozoic times.

\section{A C K N O W LED G M ENTS}

This research was sponsored by CIMERA /Centre of Excellence for Integrated Mineral and Energy Resource Analysis), the National Research Foundation (South Africa), and Sibanye Stillwater. We also gratefully acknowledge support from Sibanye Stillwater for the 3D seismic data. We also thank Schlumburger for supporting the Seismic Research Centre at the University of Witwatersrand with Petrel software licences. We declare that there is no conflict of interest according to the publishing ethics policy of the journal. 


\section{REFERENCES CITED}

Abou-Shakra, F. R. 2003. Biomedical applications of inductively coupled plasma mass spectrometry (ICP-MS) as an element-specific detector for chromatographic separations. In Wilson, I. D., ed. Bioanalytical separations. Vol. 4 of Handbook of analytical separations. Amsterdam, Elsevier, p. 351-371.

Agangi, A.; Hofmann, A.; Rollion-Bard, C.; MarinCarbonne, J.; Cavalazzi, B.; Large, R.; and Meffre, S. 2015. Gold accumulation in the Archaean Witwatersrand basin, South Africa - evidence from concentrically laminated pyrite. Earth-Sci. Rev. 140:27-53.

Alexandre, P.; Andreoli, M. A. G.; Jamison, A.; and Gibson, R. L. 2006. ${ }^{40} \mathrm{Ar} /{ }^{39} \mathrm{Ar}$ age constraints on lowgrade metamorphism and cleavage development in the Transvaal Supergroup (central Kaapvaal craton, South Africa): implications for the tectonic setting of the Bushveld Igneous Complex. S. Afr. I. Geol. 109:393410.

Altermann, W., and Nelson, D. R. 1998. Sedimentation rates, basin analysis and regional correlations of three Neoarchaean and Palaeoproterozoic sub-basins of the Kaapvaal craton as implied by precise U-Pb zircon ages from volcaniclastic sediments. Sediment. Geol. 120: 225-256.

Armstrong, R. A.; Compston, W.; Retief, E. A.; Williams, I. S.; and Welke, H. J. 1991. Zircon ion microprobe studies bearing on the age and evolution of the Witwatersrand triad. Precambrian Res. 53:243-266.

Barton, E. S., and Hallbauer, D. K. 1996. Trace-element and $\mathrm{U}-\mathrm{Pb}$ isotope compositions of pyrite types in the Proterozoic Black Reef, Transvaal Sequence, South Africa: implications on genesis and age. Chem. Geol. 133:173199.

Blane, C. R. 2013. Composition and provenance of the Mesoarchaean Witwatersrand Subgroup, South Africa. $\mathrm{PhD}$ thesis, University of Johannesburg, $156 \mathrm{p}$.

Blenkinsop, T. G., and Doyle, M. G. 2014. Structural controls on gold mineralization on the margin of the Yilgarn craton, Albany-Fraser orogen: the Tropicana deposit, Western Australia. I. Struct. Geol. 67:189-204.

Bose, P. K.; Eriksson, P. G.; Sarkar, S.; Wright, D. T.; Samanta, P.; Mukhopadhyay, S.; Mandal, S.; Banerjee, S.; and Altermann, W. 2012. Sedimentation patterns during the Precambrian: a unique record? Mar. Pet. Geol. 33:34-68.

Buick, I. S.; Maas, R.; and Gibson, R. 2001. Precise U$\mathrm{Pb}$ titanite age constraints on the emplacement of the Bushveld Complex, South Africa, I. Geol. Soc. Lond. 158:3-6.

Camiré, G. E.; Laflèche, M. R.; and Ludden, J. N. 1993. Archaean metasedimentary rocks from the northwestern Pontiac Subprovince of the Canadian Shield: chemical characterization, weathering and modelling of the source areas. Precambrian Res. 62:285-305.

Cawthorn, R. G. 2015. The geometry and emplacement of the Pilanesberg Complex, South Africa. Geol. Mag. 152: 802-812.
Clay, A. N. 1986. The stratigraphy of the Malmani dolomite subgroup in the Carletonville area, Transvaal: Genetic implications for lead-zinc mineralization. In Anhaeusser, C. R., and Maske, S., eds. Mineral deposits of southern Africa. Johannesburg, Geol. Soc. S. Afr., p. 853-860.

Condie, K. C. 1993. Chemical composition and evolution of the upper continental crust: contrasting results from surface samples and shales. Chem. Geol. 104:1-37.

Cooke, D. R., and Simmons, S. F. 2000. Characteristics and genesis of epithermal gold deposits. In Hagemann, S. G., and Brown, P. E., eds. Gold in 2000. Rev. Econ. Geol. 13:221-244.

da Costa, G.; Hofmann, A.; and Agangi, A. 2017. Provenance of detrital pyrite in Archaean sedimentary rocks: examples from the Witwatersrand Basin. In Mazumder, R., ed. Sediment provenance: influences on compositional change from source to sink. Amsterdam, Elsevier, p. 509-531.

Els, B. G.; van den Berg, W. A.; and Mayer, J. J. 1995. The Black Reef Quartzite formation in the western Transvaal: sedimentological and economic aspects, and significance for basin evolution. Miner. Dep. 30:112-123.

Eriksson, P. G.; Altermann, W.; and Hartzer, F. J. 2006. The Transvaal supergroup and precursors. In Johnson, M. R.; Anhaeusser, C. R.; and Thomas, R. J., eds. The geology of South Africa. Johannesburg, Geol. Soc. S. Afr., p. 237260.

Frankel, J. J. 1940. Notes on some of the minerals in the Black Reef series. Trans. Geol. Soc. S. Afr. 43:1-9.

Frey, M. 1988. Zur Metallogenese von Gold-Uran Paläoseifen in der Black Reef Formation der TransvaalSupergruppe Südafrika. $\mathrm{PhD}$ thesis, University of Cologne.

Frey, M.; Germs, G. J. B.; Oberthür, T.; and Saager, R. 1991. Textural and compositional characteristics of gold, sulphides and tourmaline in the Black Reef palaeoplacer, Transvaal sequence, South Africa. Internal research report, University of Cologne.

Frimmel, H. E. 1994. Metamorphism of Witwatersrand gold. Explor. Min. Geol. 3:357-370.

- 2014. A giant Mesoarchean crustal goldenrichment episode: possible causes and consequences for exploration. In Kelley, K. D., and Golden, H. C., eds. Building exploration capability for the 21st century. Soc. Econ. Geol. Spec. Publ. 18:209-234.

- 2018. Episodic concentration of gold to ore grade through Earth's history. Earth-Sci. Rev. 180:148-158.

Frimmel, H. E., and Gartz, V. H. 1997. Witwatersrand gold particle chemistry matches model of metamorphosed, hydrothermally altered placer deposits. Miner. Dep. 32:523-530.

Frimmel, H. E.; Hallbauer, D. K.; and Gartz, V. H. 1999. Gold mobilizing fluids in the Witwatersrand Basin: composition and possible source. Mineral. Petrol. 66: 55-81. 
Frimmel, H. E., and Minter, W. E. L. 2002. Recent developments concerning the geological history and genesis of the Witwatersrand gold deposits, South Africa. In Goldfarb, R. J., and Nielsen, R. G., eds. Integrated methods for discovery: global exploration in the twenty-first century. Soc. Econ. Geol. Spec. Publ. 9:1745.

Fuchs, S.; Williams-Jones, A. E.; and Przybylowicz, W. J. 2016. The origin of the gold and uranium ores of the Black Reef Formation, Transvaal Supergroup, South Africa. Ore Geol. Rev. 72:149-164.

Gammons, C. H., and Williams-Jones, A. E. 1997. Chemical mobility of gold in the porphyry-epithermal environment. Econ. Geol. 92:45-59.

Gauert, C. D. K.; Deacon, J.; and Fuchs, S. 2010. Mineralogy and geochemistry of the Black Reef Au mineralisation at Consolidated Modderfrontein, East Rand, South Africa. Acta Mineral.-Petrograph. Abstr. Ser. 6:302.

Germs, G. J. B. 1982. A palaeogeographical study of the Black Reef Formation of the Transvaal Supergroup in the Ventersdorp-Balfour area. JCI (Johannesburg Consolidated Investment) Report no. 136.

Gibson, R. L.; Reimold, W. U.; and Stevens, G. 1998. Thermal-metamorphic signature of an impact event in the Vredefort dome, South Africa. Geology 26:787790.

Glazner, A. F. 1988. Stratigraphy, structure, and potassic alteration of Miocene volcanic rocks in the Sleeping Beauty area, central Mojave Desert, California. Geol. Soc. Am. Bull. 100:424-435.

Graton, L. C. 1930. Hydrothermal origin of the Rand gold deposits. Part 1. Testimony of the conglomerates. Econ. Geol. 25(3 suppl.):1-185.

Hanson, R. E.; Harmer, R. E.; Blenkinsop, T. G.; Bullen, D. S.; Dalziel, I. W. D.; Gose, W. A.; Hall, R. P.; et al. 2006. Mesoproterozoic intraplate magmatism in the Kalahari Craton: a review. I. Afr. Earth Sci. 46:141-167.

Harley, M., and Charlesworth, E. G. 1994. Structural development and controls to epigenetic, mesothermal gold mineralization in the Sabie-Pilgrim's Rest goldfield, eastern Transvaal, South Africa. Explor. Min. Geol. 3:231-246.

Hayward, C. L.; Reimold, W. U.; Gibson, R. L.; and Robb, L. J. 2005. Gold mineralisation within the Witwatersrand basin, South Africa: evidence for a modified placer origin, and the role of the Vredefort impact event. In McDonald, I.; Boyce, A. J.; Butler, I. B.; Herrington, R. J.; and Polya, D. A., eds. Mineral deposits and Earth evolution. Geol. Soc. Lond. Spec. Publ. 248:31-58.

Henry, G., and Master, S. 2008. Black Reef Project. Internal report. Council for Scientific and Industrial Research (CSIR) and University of the Witwatersrand.

Hofmann, A.; Bekker, A.; Rouxel, O.; Rumble, D.; and Master, S. 2009. Multiple sulphur and iron isotope composition of detrital pyrite in Archaean sedimentary rocks: a new tool for provenance analysis. Earth Planet. Sci. Lett. 286:436-445.

Kamo, S. L.; Reimold, W. U.; Krogh, T. E.; and Colliston, W. P. 1996. A $2.023 \mathrm{Ga}$ age for the Vredefort impact event and the first report of shock metamorphosed zircons in pseudotachylitic breccias and granophyre. Earth Planet. Sci. Lett. 144:369-387.

Killick, A. M. 1993. Pseudotachylites of the West Rand goldfield, Witwatersrand basin, South Africa. PhD thesis, Rand Afrikaans University, Johannesburg.

Kirk, J. D. 2004. Rhenium-osmium systematics of orogenic gold deposits through geologic time. $\mathrm{PhD}$ dissertation, University of Arizona, Tucson.

Knoll, A. H., and Beukes, N. J. 2009. Introduction: initial investigations of a Neoarchean shelf margin-basin transition (Transvaal Supergroup, South Africa). Precambrian Res. 169:1-14.

Koglin, N.; Frimmel, H. E.; Minter, W. E. L.; and Brätz, H. 2010. Trace-element characteristics of different pyrite types in Mesoarchaean to Palaeoproterozoic placer deposits. Miner. Dep. 45:259-280

Manzi, M. S. D.; Cooper, G.; Malehmir, A.; Durrheim, R.; and Nkosi, Z. 2015. Integrated interpretation of 3D seismic data to enhance the detection of the goldbearing reef: Mponeng gold mine, Witwatersrand Basin (South Africa). Geophys. Prospect. 63:881-902.

Manzi, M. S. D.; Hein, K. A. A.; King, N.; and Durrheim, R. J. 2013. Neoarchaean tectonic history of the Witwatersrand Basin and Ventersdorp Supergroup: new constraints from high-resolution 3D seismic reflection data. Tectonophysics 590:94-105.

Martin, D. M.; Clendenin, C. W.; Krapež, B.; and McNaughton, N. J. 1998. Tectonic and geochronological constraints on late Archaean and Palaeoproterozoic stratigraphic correlation within and between the Kaapvaal and Pilbara Cratons. I. Geol. Soc. Lond. 155: 311-322.

Master, S. 1984. A facies analysis and palaeoenvironmental interpretation of the Black Reef Formation on the western side of the Johannesburg Dome. Unpublished report, Dept. Geol., University of the Witwatersrand.

McLoughlin, A. C. 2014. Geometallurgical examination of gold, uranium and thorium in the Black Reef Quartzite Formation, Gold One International LTD, Springs. MSc thesis, University of Johannesburg.

Meyer, F. M., and Robb, L. J. 1996. The geochemistry of black shales from the Chuniespoort Group, Transvaal Sequence, eastern Transvaal, South Africa. Econ. Geol. 91:111-121.

Minter, W. E. L. 1976. Detrital gold, uranium, and pyrite concentrations related to sedimentology in the Precambrian Vaal Reef placer, Witwatersrand, South Africa. Econ. Geol. 71:157-176. . 1999. Irrefutable detrital origin of Witwatersrand gold and evidence of eolian signatures. Econ. Geol. 94: 665-670.

Minter, W. E. L., and Loen, J. S. 1991. Palaeocurrent dispersal patterns of Witwatersrand gold placers. S. Afr. J. Geol. 94:70-85.

Nesbitt, H. W. 1992. Diagenesis and metamorphism of weathering profiles, with emphasis on Precambrian palaeosols. In Martini, I. P., and Chesworth, W., eds. Weathering, soils and paleosols. Amsterdam, Elsevier, p. 127-152. 
Nesbitt, H. W., and Young, G. M. 1989. Formation and diagenesis of weathering profiles. I. Geol. 97:129-147.

Nkosi, N. Z.; Manzi, M. S. D.; Brovko, O.; and Durrheim, R. J. 2018. 3D seismic attributes for structural mapping and enhancement of deep gold mining: a case study from the West Wits Line goldfields, South Africa. Explor. Geophys. 49:345-362.

Nwaila, G.; Frimmel, H. E.; and Minter, W. E. L. 2017. Provenance and geochemical variations in shales of the Mesoarchean Witwatersrand Supergroup. I. Geol. 125: 399-422.

Pedersen, S. I.; Randen, T.; Sonneland, L.; and Steen, O. 2002. Automatic 3D fault interpretation by artificial ants. European Association of Geoscientists and Engineers Conference, 64th (Florence), Exp. Abstr. G-37.

Phillips, G. N., and Law, J. D. M. 1994. Metamorphism of the Witwatersrand gold fields: a review. Ore Geol. Rev. 9:1-31.

Phillips, G. N., and Powell, R. 2015. Hydrothermal alteration in the Witwatersrand goldfields. Ore Geol. Rev. 65:245-273.

Ramdohr, P. 1958. New observations on the ores of the Witwatersrand in South Africa and their genetic significance. Trans. Geol. Soc. S. Afr. 61(Annex.):1-50.

Rijks, E. J. H., and Jauffred, J. C. E. M. 1991. Attribute extraction: an important application in any detailed 3-D interpretation study. Leading Edge 10(9):11-19.

Robb, L. J.; Charlesworth, E. G.; Drennan, G. R.; Gibson, R. L.; and Tongu, E. L. 1997. Tectono-metamorphic setting and paragenetic sequence of Au-U mineralisation in the Archaean Witwatersrand Basin, South Africa. Aust. I. Earth Sci. 44:353-371.

Rock Deformation Research. 2004. Structural and seismic appraisal of the kloof and surrounding area. Report 9350, $37 \mathrm{p}$

Seward, T. M., and Barnes, H. L. 1997. Metal transport by hydrothermal ore fluids. In Barnes, H. L., ed. Geochemistry of hydrothermal ore deposits (3rd ed.). New York, Wiley, p. 435-486.

Sibson, R. H., and Scott, J. 1998. Stress/fault controls on the containment and release of overpressured fluids: examples from gold-quartz vein systems in Juneau, Alaska; Victoria, Australia and Otago, New Zealand. Ore Geol. Rev. 13:293-306.

Smith, A. J. B.; Beukes, N. J.; and Gutzmer, J. 2013. The composition and depositional environments of Mesoarchean iron formations of the West Rand Group of the Witwatersrand Supergroup, South Africa. Econ. Geol. 108:111-134.

Spellman, R. L. 1986. Northeast prospect (NEP) shaft high-grade gold placer: a feeder channel into the East
Rand Black Reef, GeoCongress '86, Extended Abstr. Johannesburg, Geol. Soc. S. Afr., p. 985-988.

Stumm, N., and Morgan, N. 1981. Aquatic chemistry: an introduction emphasizing chemical equilibria in natural waters (2nd ed.). New York, Wiley.

Sumner, D. Y., and Beukes, N. J. 2006. Sequence stratigraphic development of the Neoarchean Transvaal carbonate platform, Kaapvaal Craton, South Africa. S. Afr. I. Geol. 109:11-22.

Swiegers, J. U. 1939. Gold, carbon, pyrite and other sulphides in the Black Reef. Trans. Geol. Soc. S. Afr. 42: 35-46.

Taylor, S. R., and McLennan, S. M. 1985. The continental crust: its composition and evolution. Oxford, Blackwell, $312 \mathrm{p}$.

Tibane, L. V. 2013. The characterization of pyrite from the Ventersdorp Contact Reef of the Kloof Gold Mine in the Witwatersrand Basin in South Africa. MSc thesis, University of Pretoria.

Trieloff, M.; Reimold, W. U.; Kunz, J.; Boer, R. H.; and Jessberger, E. K. 1994. ${ }^{40} \mathrm{Ar}-{ }^{39} \mathrm{Ar}$ thermochronology of pseudotachylite at the Ventersdorp Contact Reef, Witwatersrand basin. S. Afr. J. Geol. 97:365-384.

van Achterbergh, E.; Ryan, C. G.; Jackson, S. E.; and Griffin, W. 2001. Data reduction software for LAICP-MS. In Sylvester, P., ed. Laser ablation ICPMS in the earth sciences: principles and applications. Mineral. Assoc. Can. Short Course 29, Vancouver, Mineral. Assoc. Can., p. 239-243.

Wallmach, T., and Meyer, F. M. 1990. A petrogenetic grid for metamorphosed aluminous Witwatersrand shales. S. Afr. J. Geol. 93:93-102.

Whymark, W. E., and Frimmel, H. E. 2018. Regional gold-enrichment of conglomerates in Paleoproterozoic supergroups formed during the $2.45 \mathrm{Ga}$ rifting of Kenorland. Ore Geol. Rev. 101:985-996.

Williams-Jones, A. E.; Bowell, R. J.; and Migdisov, A. A. 2009. Gold in solution. Elements 5:281-287.

Zartman, R. E., and Frimmel, H. E. 1999. Rn-generated ${ }^{206} \mathrm{~Pb}$ in hydrothermal sulphide minerals and bitumen from the Ventersdorp Contact Reef, South Africa. Mineral. Petrol. 66:171-191.

Zeh, A.; Ovtcharova, M.; Wilson, A. H.; and Schaltegger, U. 2015. The Bushveld Complex was emplaced and cooled in less than one million years-results of zirconology, and geotectonic implications. Earth Planet. Sci. Lett. 418:103-114.

Ziemniak, S. E.; Jones, M. E.; and Combs, K. E. S. 1993. Solubility and phase behavior of $\mathrm{Cr}$ (III) oxides in alkaline media at elevated temperatures. I. Solut. Chem. 27:3366. 